\title{
O Dilúvio de Noé e os primórdios da Geologia
}

\author{
Ernesto Luiz Correa Lavina ${ }^{1}$
}

\begin{abstract}
Resumo O tempo tecnológico, detalhista e acelerado que vivenciamos, é notavelmente diferente do mundo medieval, em termos científicos e culturais. A ruptura surge já na metade do século XVII, quando uma radical transformação na visão de mundo dos homens cultos europeus gerou condições para construção do mundo natural. Não que a natureza estivesse ausente, mas sua percepção era notavelmente distinta. Durante a alta idade média (século IV d.C.), o cristianismo e a idealização de um Deus Criador tornaram-se dominantes, implicando certa ligação direta entre Deus e os fenômenos naturais. No início do século XVII, a forma de pensar a natureza era essencialmente medieval, mas o sucesso do Universo máquina/mecânico, associado ao desenvolvimento da Astronomia, Física e Química e dos primeiros instrumentos modernos, possibilitou um novo relacionamento com o mundo natural. Muitos sábios direcionaram sua atenção ao Dilúvio Universal, devido à extraordinária importância deste acontecimento para o mundo cristão. Em menos de cinquenta anos, os fósseis foram compreendidos como vestígios de seres antigos e o Dilúvio foi analisado, subdividido em eventos e reconstruído como hipótese científica. Além disso, percebeu-se que a paisagem não era imutável, e que as montanhas evoluíram a partir de antigas bacias oceânicas. Nestes anos, foi iniciado o desenvolvimento de muitos princípios fundamentais da Geologia. Mas a atitude mais profunda e decisiva para formação do pensamento moderno foi a compreensão das transformações naturais do planeta sem a intervenção de um Deus Criador. Hoje, perdemos a percepção da notável origem do pensamento geológico, bem como de sua importância para a separação radical entre religião e ciência.
\end{abstract}

Palavras-chave: similitude, pensamento analítico, fósseis, episteme, Foucault.

\begin{abstract}
The Noah's flood and the beginnings of Geology. The detailed and accelerated technological time that we experience today, when contrasted with the medieval world, reveals a remarkable difference in scientific and cultural patterns. The rupture appears in the mid-seventeenth century, when a radical transformation in the worldview of the educated European men created conditions for the construction of the natural world. Nature was not absent, but perceived by a remarkably distinct way. During the High Middle Ages (fourth century AD), Christianity and the idea of a God creator of man, earth and universe, became dominant in Europe, inducing a direct link between God and natural phenomena. In the early sixteenth's century (renaissance) the nature of thought was essentially criationist, but from the huge success of the machine/ mechanical universe, associated with the great development of Astronomy, Physics and Chemistry, and the first modern instruments, in the seventeenth's century comes a new relationship with the natural world. Many scholars have directed attention to the Deluge, due to the extraordinary importance of this event for Christianity. In less than one hundred years the Deluge was analyzed, subdivided into events, and rebuilt as a scientific hypothesis. Throughout this time there was an understanding of fossils as remains of ancient beings, and that existed in the past beings, different than today. Moreover, there was the understanding that the landscape was mutable, and that the mountains have evolved from ancient ocean basins. In those years, the fundamental principles of geology were developed. The most crucial point, decisive for the formation of modern thought, was the acceptance that the planet's natural transformations occur without the intervention of a Creator God. Today we have lost the perception of the origin of geological thinking and its importance to the radical separation between religion and science.
\end{abstract}

Keywords: similitude, analytical thinking, fossils, episteme, Foucault.

INTRODUÇÃO A segunda metade do século XVII foi um tempo de extraordinária agitação intelectual. Como novidade, estava em progresso uma forma nova de abordagem do mundo natural. O mundo estava deixando de ter uma ordenação preestabelecida (divina) e já era possível pensar a natureza em termos de identidades e diferenças, sempre que possível expressas em linguagem matemática. Houve a transformação da física, da química (alquimia) e da astronomia do senso comum em ciências matematizadas. Mas os questionamentos foram muito mais abrangentes. Parte da atenção se direcionou à natureza dos fósseis. Vestígios de seres marinhos sobre os continentes, e mesmo no alto das montanhas, exerciam enorme fascínio sobre os homens cultos. Na Inglaterra, a origem orgânica dos fósseis podia ser discutida abertamente, e induzia, de modo quase direto, ao dilúvio bíblico. Os fósseis também lançavam dúvidas sobre a permanência (ou a constância) 
do relevo ao longo do tempo. Surgiu a ideia de que as montanhas não eram imutáveis, mas possuíam um ciclo de existência, desde o soerguimento abrupto do assoalho oceânico até o posterior rebaixamento por erosão. Nessa época foi gerada uma produção bibliográfica que, embora hoje não faça parte da ciência formal, é fundamental para a compreensão da evolução do pensamento científico.

Procuraremos demonstrar que o século XVII, assim como se associa à fundação da Física e da Química, foi decisivo para o posterior desenvolvimento da Geologia. Muitos sábios notáveis foram progressivamente direcionando sua atenção para o estudo das rochas. Sua motivação era de natureza religiosa: queriam tornar científico o Dilúvio Universal. Suas teorias, exóticas e sem fundamento ao primeiro olhar, são radicais e profundas em suas implicações, desde que vistas contextualizadas à época. Nesta tentativa, desenvolveram princípios fundamentais e, ao mesmo tempo, geraram muitos conflitos com os teólogos e a Igreja cristã. Este aspecto da produção intelectual dos naturalistas do século XVII encontra-se ausente na grande maioria das análises históricas modernas. A tentativa de tornar o Dilúvio Universal uma hipótese científica fez aflorar graves problemas com relação ao teor das Escrituras Sagradas. Conflitos tão importantes quanto os decorrentes dos avanços da Astronomia e da Física teórica.

A transição do pensamento medieval para o pensamento moderno passa, necessariamente, além dos sempre discutidos Galileu, Newton, Boyle e Descartes, também por esses naturalistas quase desconhecidos, sistematicamente esquecidos nos históricos sobre a evolução da ciência. Temos dificuldades em percebê-los talvez porque, olhando para um passado nem tão distante em termos temporais, somos separados por uma cultura totalmente distinta. Ao longo dos séculos XIX e XX, fomos perdendo progressivamente a noção da importância do Dilúvio Universal para a construção do pensamento ocidental.

Este texto irá se restringir à análise da segunda metade do século XVII e primeira década do século XVIII, por sua importância para o desenvolvimento do pensamento científico. Este período, usualmente associado ao mecanicismo, corresponde a uma tentativa de ordenação e matematização do mundo natural (máthêsis) e é associado por Foucault (1985) com o início da episteme clássica. Cabe destacar que o mecanicismo não se restringiu ao pensamento de René Descartes ou a ciências como Astronomia, Física e Química, mas também propôs modelos teóricos para domínios do saber muito diferenciados, entre eles, fósseis e rochas (Foucault 1985). Por se associar a uma mudança no modo de pensar e de agir, revelando um novo horizonte do saber e uma nova compreensão da realidade, este tempo é considerado por alguns historiadores como o ponto de partida do iluminismo, que dominará o século XVIII (e.g. Cassirer 1992).

Para embasar a análise, necessitamos discutir, com algum detalhe, a estrutura do pensamento medieval e renascentista, para buscar a sua forma de representação do mundo, o princípio da ordenação dos saberes. Sobre as regras de formação do discurso criacionista, abordaremos a inserção progressiva do pensamento direcionado para o estudo das rochas e fósseis, em sua tentativa de comprovação do Dilúvio Universal. Ao final discutiremos como foi possível a transformação do pensamento que deu forma ao mundo moderno e, em consequência, à Geologia.

Tentaremos ainda delimitar um problema com as análises históricas presentes na maior parte dos livros técnicos de Geologia. As abordagens efetuadas a partir de recortes insuficientes levam a uma representação da história descomprometida com os fatos reais. Gera tanto a figura do herói, o que viu antes, falou antes, e não foi compreendido pelos demais, quanto invisibilidade, pesquisadores importantes que não são percebidos porque, no caso, sua principal motivação era de cunho religioso. Como exemplo marcante de contradições nas resenhas históricas, cabe destacar Nicolas Steno, "filósofo esquecido" pela ciência moderna na opinião de Hansen (2009), mas retratado como o fundador da Geologia por Schoch (1989). Quando presente nos históricos dos livros técnicos, Steno aparece quase sempre descontextualizado, incompreensível se pensarmos em uma Europa cristã e crente nas Escrituras Sagradas.

Cabe destacar que a abordagem histórica foi desenvolvida a partir da análise dos textos originais dos naturalistas do século XVII, e não considerou a opinião que os analistas da segunda metade do século XVIII e do século XIX expressaram sobre eles. Este procedimento foi necessário para evitar conflitos de interpretação. Hoje, o dilúvio universal não se encontra mais no domínio da ciência, e o artigo não trata, portanto, de construir uma argumentação para demonstrar que os “diluvianistas" estavam errados em sua premissa central. O objetivo é apresentar a originalidade de um modo de pensar a natureza no início da era da ciência, com ênfase nas rochas sedimentares e fósseis, e destacar sua importância para a formação do pensamento científico. Cabe também referir que a organização histórica se ampara na notável reconstrução do pensamento dos naturalistas do século XVII, elaborada por Ruth Moore no livro "The Earth we live on" (Moore 1956; p. 34 a 46).

O mundo medieval e renascentista Entender o pensamento criacionista medieval, bem como sua origem, não é tarefa fácil para quem vivencia o tempo atual. 
Para William C. Bark, a "idade média” foi a consequência obrigatória da decadência e colapso gradual da infraestrutura física e econômica do império romano do ocidente. A nova sociedade, agrária, pobre e desorganizada, foi progressivamente se distanciando da cultura greco-romana. Não foi uma escolha, fora o único caminho possível (Bark 1979).

No início da Alta Idade Média (século IV), tornou-se hegemônica uma forma de pensar o homem e a natureza que agregava elementos judaico-cristãos e do pensamento grego. Muitos séculos foram necessários para encontrar a formulação ideal, expressa por (Santo) Agostinho (354-430) no ano de 413 d.C. (Sá 1944). Era um sistema determinado, hierarquizado, no qual a novidade, em princípio, não era possível. Havia uma contínua exegese (esclarecimento) dos textos sagrados e do pensamento dos padres da Igreja; o sistema não podia conviver com conflitos de interpretação. As verdades universais e necessárias (= Conhecimento) eram simples e fundamentais, não cabendo questionamento. $\mathrm{O}$ Conhecimento não se constituía em problema, pois era obtido por dedução. Era um saber definitivo, completo, suficiente, embora sempre passível de detalhamento. Um sistema hierárquico vigiava continuamente toda a produção intelectual, sempre analisando o ajuste das novas deduções dentro do sistema teórico, delimitando possíveis conflitos e exigindo reparação ou mesmo punindo as interpretações discrepantes (Russell 1982). Fora do espaço restrito das verdades simples e fundamentais, havia a "opinião", manifesta para tudo aquilo que não eram verdades absolutas. Neste domínio, os saberes como medicina e alquimia encontravam o seu espaço; saberes úteis, porém, sem qualquer nobreza, sem qualquer possibilidade de ser transformados em Conhecimento (Hacking 1995).

A interpretação das coisas do mundo era desenvolvida com base nos acontecimentos e relações observados nas experiências sensoriais do dia a dia. Substância, essência, matéria, forma, movimento, quantidade e qualidade eram categorias que permitiam a interpretação do mundo. Gelo e vapor ou frio e calor eram substâncias diferentes (Burtt 1983). Os corpos pesados descem para o seu lugar natural, porém de modo organizado: a água fica acima da terra, onde não tem peso. Mudança e movimento eram categorias especiais; os corpos que se movem se transformam. Deus, em sua imobilidade, induz as transformações, é a causa de todas as mudanças, e a origem de todo o movimento (Sá 1944). E o movimento é sempre absoluto, não depende de um referencial; quando se move, um corpo se desloca em relação a todo o Universo. O tempo era concebido como uma função do movimento, o presente está imóvel e atrai o futuro para si (Russell 1982, Burtt 1983, Kuhn 1989).
Na Idade Média, o homem é o fator determinante do mundo, superior hierárquico à natureza, cujo único propósito é servir: fornecer abrigo, materiais de construção, alimentos (Burtt 1983). Como na aquisição do conhecimento só o homem é ativo, quando o homem vê - algo sai de seus olhos em sentido ao objeto. E o que é percebido no objeto constitui a realidade do objeto (Russell 1982).

Era um mundo mais simples de se viver, criado por Deus para atender às necessidades do homem, para favorecê-lo se fosse bom, para puni-lo em caso de desvios. Secas, inundações, pragas, terremotos, doenças e mesmo mortes súbitas não se deviam às transformações naturais do planeta ou dos seres humanos, se inseriam em um contínuo de punições. Nada era natural, tudo tinha uma explicação divina: a chuva provém das nuvens, é certo, mas chove por desígnios divinos (benefício ou punição).

A filosofia medieval era voltada para explicar os porquês últimos dos fenômenos, estava articulada sobre o "princípio da causalidade final". Não havia a necessidade de explicar as causas imediatas que ligavam os fatos do mundo. Funcionava como uma ligação direta, uma forma de pensar o mundo que culminava em Deus (Sá 1944). As explicações dos fenômenos eram dadas principalmente em termos de uso pelo homem, uma concessão de Deus, para nosso benefício (Russell 1982). O Universo encontrava-se imediatamente presente e plenamente inteligível pela mente humana (Burtt 1983). A Terra, sólida, imensa e, fato fundamental, em repouso, ocupava o centro do reino astronômico (Cresson 1963). No Universo pequeno e finito, Sol, estrelas, lua e planetas estavam dispostos em uma esfera leve e não muito distante, que existia para aprendizagem, orientação em viagens e satisfação.

Neste sistema organizado e ordenado, o passado do homem e da Terra estava contido na Bíblia. Para saber o momento da criação, ou, dito de outra forma, a idade da Terra, bastava somar as idades dos patriarcas. Esta tarefa foi efetivamente realizada pelo bispo de Usher, em 1650: Deus criou a Terra no dia 26 de outubro do ano 4004 a.C. (Moore 1956). Apesar de tudo o que possamos hoje pensar dessa análise, as implicações, no contexto social da época, foram tão extraordinárias quanto às da datação radiométrica de 4,6 bilhões de anos (4,6 Ga) para a idade da Terra de 1956. Gerou um modo de pensar os fenômenos geológicos que só foi efetivamente alterado a partir do início do século XX.

No mundo medieval, com sua noção de tempo restrito aos acontecimentos humanos, não era possível estabelecer considerações sobre um tempo anterior ao homem, pois este seria um tempo Divino, não cabendo qualquer tipo de especulação (Russell 1982). Todos os fatos do mundo ocorreram pós-criação, com a presença 
do homem, com o seu testemunho. Deste modo, quando se encontrava um fóssil: uma pedra que parecia concha ou osso, isto era só coincidência. Afinal, como poderiam virar pedra? Mais complicado ainda, conforme argumentavam alguns, existiam fósseis que lembravam ossos de animais muitas vezes maiores que os elefantes atuais, animais que teriam desaparecido da Terra (hoje dinossauros). Este tipo de especulação criava um problema adicional, pois além da questão da petrificação, havia um grande conflito, pois está escrito na Bíblia que Noé salvou um casal de todos os animais e, portanto, nenhuma espécie desapareceu por conta do Dilúvio. Nas discussões envolvendo, um século antes, as opiniões de Leonardo da Vinci (1452-1519) sobre determinados fósseis serem restos de organismos antigos, a polêmica não estava localizada na sua semelhança maior ou menor com seres atuais, nem mesmo no fato de terem se transformado em pedra, pois isso não era importante nos debates. Por detrás das batalhas verbais pairava a questão de Noé ter esquecido algumas espécies, algo impossível de ter ocorrido. Além disso, havia sempre a possibilidade de ser uma artimanha do demônio: produzir fósseis para induzir dúvidas sobre a veracidade da Bíblia. Isto era uma possibilidade real à época.

A partir do século XIII (Baixa Idade Média), passam a ocorrer mudanças importantes na organização social e na separação entre a função do conhecimento e a função da Revelação (Coelho 1988). O comércio e os bancos apresentam papel econômico crescente, e o banqueiro e o burguês assumem aos poucos o lugar do nobre (Russell 1982). Nos segmentos de maior cultura, a tradução de filósofos gregos e árabes facilitou a difusão do pensamento grego clássico. No século XVI (renascença), a Reforma e as guerras fizeram o papado perder parte do poder e houve, em paralelo, o aumento do poder real. O desgaste da guerra dos trinta anos (1618-1648) auxiliou o desenvolvimento do ensino secular, levado a cargo pelos jesuítas, abordando também matemática e ciências (Russell 1982).

Todas as mudanças vão desembocar, no século XVII, com o início de uma modificação radical nas relações sociais. Atrelando o poder ao saber, a burguesia produziu notável invenção: um novo mecanismo de poder, que ultrapassou o século XVII e deu forma ao mundo moderno. Um conjunto amplo de estratégias de utilização eficiente dos seres humanos, definidas por Foucault (1999a) como "poder disciplinar", destinadas a melhorar a produtividade geral do trabalho, se disseminou pelos segmentos sociais, construindo, progressivamente, indivíduos hábeis, eficientes e úteis (Foucault 1998). Técnicas simples e variadas envolvendo exercícios, adestramento, repetição de movimentos, distribuição do tempo e atenção a horários, concentração e assimilação de regras, destinavam-se a reduzir desperdícios e perdas de tempo, e a tornar o trabalho humano sempre mais rentável. A sociedade foi se tornando progressivamente disciplinar (organizada, metódica e detalhista) e direcionou parte de sua atenção ao mundo natural, produzindo saberes de um novo tipo, cuja base não era mais a autoridade das Escrituras Sagradas (Foucault 1998).

\section{O SÉCULO XVII E O NASCIMENTO DE UM MODO NOVO DE RELAÇÃO COM A NATURE-}

ZA O século XVII costuma ser relacionado diretamente aos grandes sábios que moldaram o mundo moderno: Johannes Kepler (1571-1630) refinou o modelo heliocêntrico de Copérnico (1473-1543) e demonstrou que os planetas percorrem órbitas elípticas; Galileu Galilei (1564-1642) aplicou a matemática à natureza e demonstrou que o movimento retilíneo uniforme é o único natural; Isaac Newton (1642-1727) criou as teorias da mecânica e da gravitação universal e o cálculo diferencial e integral; uniu a matemática ao experimento, e provou que, uma vez posto em movimento, um corpo continua a mover-se para sempre, a menos que haja a intervenção de uma força externa; William Gilbert (1544-1603) desenvolveu a ideia de que a Terra é um ímã gigantesco; Edmond Halley (1656-1742), juntamente com Newton, desmistificou os cometas, demonstrando que seguem órbitas elípticas ao redor do Sol; Gottfried Leibnitz (1646-1716) criou o cálculo infinitesimal, independente de Newton, e o sistema binário; John Napier (1550-1617) criou os logaritmos, fundamentais ao cálculo diferencial e integral de Newton e Leibnitz; Robert Boyle (1627-1691) formulou, na tradição inglesa, os princípios da química moderna; John Locke (1632-1704) fundou o empirismo, segundo o qual o conhecimento deriva da experiência, e o mundo consistiria só de matéria em movimento; Francis Bacon (1561-1626) desenvolveu o método indutivo moderno; e René Descartes (1596-1650), incluído por último, mas certamente um dos primeiros em importância, pois além de ser um dos criadores da ciência (inventor da geometria analítica), foi o fundador da filosofia moderna (Russell 1982, Burtt 1983, Kuhn 1976, Koyré 1961, 1986, Cassirer 1992, Sá 1944, Casini 1995).

Novos instrumentos e importantes descobertas iniciaram, no século XVII, o imenso detalhamento do mundo atual: microscópio (de 1590, mas com importância apenas no século XVII), luneta (1608; Lippershey), telescópio (1610; Galileu), barômetro (1643; Torricelli), bomba de ar (1654; Guericke), termômetro (1664; Galileu), máquina a vapor (1679; Papin, 1698; Savery) e o extraordinário aperfeiçoamento do relógio (1640; Galileu, 1650 e 1675; Huygens). Em sequência aos instrumentos, houve uma série de 
descobertas, entre elas a dos protozoários e do espermatozoide (1653 e 1677; Leeuwenhoek) e da circulação do sangue (1628; Harvey). Athanasius Kircher (16021680), padre jesuíta, utilizando o microscópio, propôs que microorganismos seriam responsáveis por muitas doenças. Ele diagnosticou, de modo correto, que uma bactéria era a responsável pela praga que se disseminou em Roma no ano de 1656.

O século XVII foi marcado pelo início do Iluminismo, o florescimento do estilo arquitetônico Barroco e de um sistema de circulação e troca de mercadorias, usualmente referido como Mercantilismo. Mas existe também outro viés bastante mais obscuro neste século. O século XVII coincidiu, em toda a Europa, com um período de crises sucessivas, que culminaram, em sua parte média, com revoluções em vários Países. As causas são variadas e difíceis de ajustar: desde as guerras e crises no sistema de produção, até conflitos com os dogmas cristãos decorrentes dos avanços da ciência, tecnologia e das novas interpretações das Escrituras Sagradas. Mais do que tudo, houve uma crise na relação entre a sociedade e o Estado (Trevor-Roper 2001). O acirramento das tensões entre protestantes e católicos, e de ambos com outros grupos (e.g. muçulmanos e judeus) ampliou perseguições por motivos religiosos e místicos. Denúncias e processos por feitiçaria e "caça as bruxas”, especialmente na Estônia, Alemanha, Inglaterra e Escócia, marcaram o século XVII (Chassot 2009). As ações eram executadas por tribunais civis, sem envolvimento direto da Igreja (Blainey 2009).

O século XVII também foi um tempo de grande expansão das profecias apocalípticas, pois o cristianismo vivia a última idade do mundo (desde o nascimento de Cristo), e aguardava, em expectativa, o final dos tempos (juízo final). Como no século anterior Lutero (1483-1546) manifestara que o fim do mundo se aproximava com grande velocidade, profecias o previam para o início do século XVIII (Koselleck 2006). Em conflito direto, Francis Bacon e Benedictus Spinoza (1632-1677) usavam diferentes abordagens para desmascarar profecias e (falsos) profetas (Cassirer 1992). A segunda metade do século XVII, entretanto, foi um tempo de extraordinário florescimento intelectual.

Para que possamos compreender a estrutura do pensamento no século XVII, necessitamos ainda de um elemento-chave, qual seja a transformação do Dilúvio bíblico em hipótese passível de análise científica.

A RELEITURA DO DILÚVIO UNIVERSAL NO SÉCULO XVII Choveu durante 40 dias e 40 noites, as águas subiram, encheram os vales e continuaram subindo até cobrir a montanha mais alta com 15 covados de água (7 m). Apenas Noé, então com seiscentos anos de idade, estava preparado para a catástrofe. A mando de Deus, o filho de Lamec, fiel, puro e contrário a todo o tipo de corrupção ou violência, construiu uma arca e levou, além da família, um casal de cada animal. Depois de cinco meses à deriva, a arca encalhou em um pico rochoso (Ararat) e, depois de mais um tempo, a Terra foi repovoada. O Dilúvio é um dos maiores eventos registrados na Bíblia, marcando o fim de uma era de corrupção e injustiças e o início de outra, de paz e prosperidade (Gênesis, capítulos 7 e 8; in: Moore 1956). O somatório das idades dos patriarcas, no momento do nascimento de cada primogênito, sugere que o Dilúvio teria ocorrido cerca de 1600 anos depois da Criação (Biblical Chronology s/data).

Escavações realizadas nas cercanias de Ur, cidade dos Caldeus e pátria de Abrahão, revelaram uma grande inundação que provocou sua destruição. Os trabalhos exaustivos de Sir Leonard Wooley na década de 1920 permitiram relacionar, ao menos como hipótese, a inundação que destruiu Ur e talvez todas as cidades da Mesopotâmia (o mundo conhecido), com o Dilúvio Universal (Moore 1956). Aparentemente, toda a região entre os Montes Zagros e o planalto da Armênia, a nordeste, e o deserto da Síria e o Grande Nefud, a sudoeste, foi inundada. Nos vales dos rios Tigre e Eufrates houve poucos sobreviventes e todo um modo de vida desapareceu (inferências a partir do estudo das cerâmicas encontradas). A história desta inundação, provavelmente recolhida pelos hebreus entre os habitantes dos vales, transformou-se em um acontecimento profundo, devastador, e chegou até nós na forma de mito sobre um acontecimento decisivo: Noé sobreviveu para dar um segundo começo à humanidade (Moore 1956).

Após 1640, surge nova abordagem do Dilúvio Universal, não mais como releitura dos textos sagrados, mas com base na análise das rochas e fósseis. Embora possam ser encontradas referências anteriores (e.g. Leonardo da Vinci e Girolano Fracastoro 1484-1553), é na segunda metade do século XVII que o tema se torna elemento comum ao discurso dos homens cultos. O texto a seguir é bastante sintético, apresentando apenas breves comentários sobre pontos específicos de obras que, por vezes, são verdadeiras cosmologias. Outros direcionamentos e mesmo visões mais abrangentes do pensamento dos naturalistas do século XVII podem ser encontradas em Moore (1956), Rudwick (1976), Gould (1982), Palmer (2005) e Menegat (2008).

O Dilúvio, a formação do relevo e a origem das montanhas No século XVII, o “nosso mundo” não estava mais contido nos vales dos rios Tigre e Eufrates; para ser universal, o Dilúvio teria que cobrir uma montanha como o Everest com cerca de sete metros de água. Por volta de 1680, o reverendo anglicano Thomas Burnet (1635-1715) discutiu a universalidade do Dilúvio, 
segundo ele, considerado por alguns homens cultos como apenas uma “...inundação nacional, confinada a Judéia e regiões próximas” (Burnet 1691; p. 26). Amparado prioritariamente nas descrições de Moisés e São Pedro, assumiu a hipótese da universalidade. Como evidência adicional, Burnet sabia que vários povos espalhados pelo mundo possuíam, entre seus mitos, referências a uma grande inundação (p. 32). Seu próximo passo foi calcular um volume de água suficiente para elevar o nível do mar até os pontos mais altos. Concluiu que seriam necessários seis a oito oceanos para produzir o Dilúvio Universal (p. 13). Burnet considerou este valor como gigantesco e absolutamente inatingível, se consideradas apenas causas naturais, tal como afirmado por Moisés e São Pedro (chuva torrencial e rompimento de fontes subterrâneas).

De onde teria vindo tanta água? De modo geral, o século XVII respondeu a esta questão referindo-se apenas a fatores endógenos, sendo raras as referências a qualquer causa externa à Terra. William Whiston (1667-1752), sucessor de Newton na Universidade de Cambridge, propôs, em 1696, que um cometa teria passado perto da Terra e, de sua cauda, vapores condensados forneceram o volume de água necessário ao Dilúvio (Whiston 1696). Outra hipótese para explicar a grande elevação das águas em função de fatores exógenos aparece apenas em comentário feito por Leibnitz em 1691 (posteriormente publicado). A Lua teria se aproximado muito da Terra, e a força de maré, enormemente ampliada, ergueu as águas, varrendo mesmo as partes mais altas. Leibnitz (1749) não aceitou esta hipótese.

Vários sábios apresentaram, de modo quase independente, uma solução notável para o problema do volume de água necessário ao Dilúvio. Em 1573, o escritor espanhol Antônio de Torquemada (1507-1569), discutindo as causas das grandes mudanças ocorridas no mundo, dissera que a Terra, antes do Dilúvio, era toda plana. Segundo ele, muitas pessoas afirmavam que as serras e os vales eram um produto do Dilúvio (Torquemada 1573; p. 131). Deste modo, muito menos água seria necessário. A partir da tradução de seu livro “Jardín de flores curiosas” para o inglês, vários entusiastas da ideia de procurar nas rochas sedimentares as evidências do Dilúvio acrescentaram informações ao modelo.

René Descartes defendeu que o sistema solar se formou a partir de um gigantesco redemoinho desenvolvido no interior do fluido universal. A Terra, na origem, era uma estrela semelhante ao Sol, que se extinguiu, em um processo envolvendo a formação e expansão de partes frias, semelhantes às manchas solares. Durante o resfriamento, a matéria se sedimentou em camadas. Após um tempo, a camada superficial fendeu e partes desmoronaram, se arranjando de modo a formar montanhas e bacias. A água, originalmente presa no interior da Terra, escapou para a superfície, encheu as depressões e formou os oceanos. A Terra guardaria ainda hoje, em seu centro, matéria em combustão (vestígio desta evolução) (Descartes 1644; Menegat 2008 apresenta análise detalhada das ideias de Descartes sobre a origem da Terra e suas implicações na evolução do pensamento geológico). Apesar de ser lido e discutido pelos filósofos "diluvianistas", as ideias de Descartes sobre a origem da Terra foram apenas parcialmente aceitas (e.g. Burnet 1691; p. 129), ou mesmo descartadas devido ao claro conflito com as Escrituras (e.g. Ray 1692; p. 135-137).

O anatomista Nicolas Steno (1638-1686) apresentou, em 1669, algumas notáveis considerações sobre a evolução tectônica do relevo. A "horizontalidade original" afirmava que as rochas sedimentares hoje dobradas e falhadas foram geradas na posição horizontal, enquanto a "superposição" deixava claro que os estratos inferiores são mais antigos que os superiores. Com relação à origem das montanhas, Steno demonstrou que os estratos que as compõem estão quebrados, inclinados em diferentes ângulos e fora de sua posição original. Sugeriu que este fenômeno poderia estar associado com súbitas explosões de gases subterrâneos ou violentas explosões de ar aprisionado em cavernas (Steno 1669; p. 229 a 231). Steno também admitia que nem todas as montanhas atuais existem desde os "primórdios das coisas”, e que as montanhas não crescem (no mesmo sentido usado para os seres; p. 232), mas podem ser aumentadas ou rebaixadas (Steno 1669; p. 234). Ele considerava que, a cada ano, um grande volume de sedimentos das montanhas é carregado para o mar pelos rios, construindo praias que se transformam em novas terras (in: Ray 1713; p. 226 - Hansen 2009 discute em profundidade a obra científica de Steno).

Em 1680, Thomas Burnet, examinando as regiões montanhosas da Europa, seus vales e também as costas recortadas dos continentes, convenceu-se de que habitamos um mundo que foi destruído durante o Dilúvio, tendo as partes sido deslocadas de seus pontos originais (Burnet 1691). Ele pedia a todos que examinassem o globo para ver as linhas onde a terra se rompera durante o Dilúvio, pois ali estavam o oceano Atlântico e o mar Vermelho. Thomas Burnet também percebia que as camadas que formavam as montanhas, dobradas e quebradas, fora de sua posição original, eram ruínas de um globo despedaçado (Burnet 1691; p. 158, 175). Ele afirmava que as rochas que formam as montanhas inicialmente estavam na posição horizontal e ocupavam um espaço maior, depois foram comprimidas em um espaço menor, e necessariamente quebraram e arquearam (p. 157-158). Em linhas gerais, sua teoria, apresentada no livro "The theory of the Earth" (Burnet 1691), afirmava que, após o caos, a Terra estava estruturada 
em um núcleo, que continha os elementos mais pesados, envolvido pela água. Na superfície, os resíduos da Criação, poeiras e partículas que estavam no ar, se depositaram sobre a água e endureceram. Desse modo, a Terra era completamente plana, sem montanhas ou oceanos (p. 10). Na época escolhida pela Providência, terremotos quebraram a crosta em grandes fragmentos, que se dissolveram parcialmente e caíram no abismo líquido (p. 172-173). Deslocadas, as águas elevaram-se e varreram a superfície, carregando as criaturas e tudo o mais. Após a imensa agitação, as águas se acalmaram, ficando restritas às depressões maiores (canal do mar; p. 177). Para Burnet, todo o processo associado ao Dilúvio devia ser construído apenas com causas físicas naturais (p. 79). Discordou das opiniões de Moisés e São Pedro sobre o milagre de a água do Dilúvio ter parcialmente brotado de fontes subterrâneas. Foi a superfície da Terra que afundou (gravidade), e o movimento relativo foi interpretado de modo errôneo pelos dois homens santos (Burnet 1691; p. 78-80 - boas análises do livro de Burnet são encontradas em Moore 1956 e Gould 1982).

Para contornar o problema do tempo, Burnet sugeriu que os dias indicados no Gênesis poderiam representar, em verdade, longas eras. Após a primeira edição do livro, Isaac Newton escreveu carta para Burnet, com vários comentários e críticas sobre as características físicas da Terra pré-diluviana (Newton 1680). Sugeriu a possibilidade de, quando Deus criou a Terra, os dias serem mais longos. Burnet rejeitou a ideia por não encontrar evidências científicas para apoiá-la (Burnet 1681).

John Ray (1628-1705), clérigo e cristão praticante, se dedicou ao estudo de plantas, e foi o primeiro a dividir as plantas com flores (angiospermas) em mono e dicotiledôneas. É mais conhecido por suas ideias com relação aos fósseis, mas talvez sua contribuição mais original esteja ligada à formação do relevo. Para Ray (1692), o relevo não é imutável, e ele construiu, nos "miscellaneous discourses", um bem elaborado e dinâmico "ciclo sedimentar" (p. 39-55). O relevo inicia por terremotos e erupções vulcânicas, que geram as áreas emersas e montanhas (estas últimas referidas como locais com estratos quebrados, penhascos e " $\mathrm{ou}$ tras desordens”; p. 169-170). As regiões elevadas são lavadas pelas chuvas que, somado ao degelo da primavera, alimentam rios que carregam grandes volumes de sedimentos para o mar (Ray 1692; p. 45). Nas praias, os sedimentos são dispersos por ondas e correntes, e se acumulam em estratos ou "assoalhos de terra e areia" que se sobrepõem aos mais antigos. Para Ray, as praias são importantes agentes de erosão e transferência de sedimentos, e se referiu a elas como "mandíbulas do mar”. A dinâmica das praias, associada à erosão fluvial, atuando ao longo de muitas eras, poderia aplainar a superfície da Terra e reduzi-la ao seu estado primitivo (Criação), quando as águas tudo cobriam. Para ele, apenas as grandes cadeias de montanhas existentes no meio dos continentes, por sua grande altura, peso e solidez, estariam a salvo de "... serem devoradas pelas mandíbulas do mar” (p. 50). Para essas, postulou a destruição pelo fogo.

Para a compreensão do pensamento de John Ray, é de fundamental importância destacar que o seu conceito de "dissolução" implica claramente em desagregação e desintegração, ou seja, ao conceito de "erosão" em seu sentido moderno. Portanto, a sua expressão "the dissolution of the world", corresponde, efetivamente, à erosão da superfície da Terra pelos rios e pelo mar (praias).

Em publicação posterior (oito anos após sua morte), Ray (1713) sugeriu um mecanismo não gravitacional para explicar a origem das montanhas. Os materiais que compõem a pólvora poderiam ter-se misturado em profundidade, pegado fogo e empurrado as rochas para acima, formando as montanhas (p. 9-10). Nesta publicação, ele consolida a ideia de que as montanhas são continuamente rebaixadas pela ação da chuva e dos rios (Ray 1713; p. 226). Após longa e exaustiva discussão, concluiu que muitas causas cooperam para rebaixar e nivelar toda a superfície acima do mar (chuvas, rios, marés, ondas, vento, fogo e terremotos) e, em consequência, compelindo as águas para retornar e cobrir a superfície seca (p. 290). O registro fossilífero sugere que isto tenha ocorrido várias vezes. Ray tentou dimensionar o seu "ciclo sedimentar", e concluiu que o sistema fluvial mundial movimenta, a cada dia, um volume equivalente a meio oceano de água (Ray 1692; p. 94-95).

De acordo com William Whiston, durante o Dilúvio, sedimentos, conchas e peixes remobilizados pelas águas (colocados em suspensão) se depositaram segundo sua gravidade específica, formando estratos ou leitos contínuos, uniformes e paralelos. Os terrenos de montanhas seriam regiões com muitas cavernas onde substâncias inflamáveis e explosivas se misturaram em grande quantidade. Quando explodiram, os estratos foram perturbados, deslocados de sua posição original (Whiston 1696; p. 424). Contrariando a opinião de quase todos os naturalistas da época, considerava que a Terra Primitiva (anterior ao Dilúvio) era semelhante à atual (p. 220 e 333).

É interessante notar que, na recontextualização do Dilúvio Universal, todos os estudiosos citados colocaram um núcleo rochoso no centro da Terra e o oceano acima. De algum modo, estão preservados os lugares naturais da terra e da água do pensamento aristotélico e escolástico. A ruptura da crosta e seu colapso podem ser entendidos como a procura do lugar natural pela 
terra que se encontrava sobre a água, em claro desequilíbrio. Cabe destacar que Steno (1669; p. 265) chamava a atenção para o fato de, na Bíblia (Gênesis 7:19), haver referência à montanhas que existiram antes do Dilúvio.

A natureza dos fósseis $\mathrm{Na}$ análise do Dilúvio Universal, os fósseis (“formed stones”) adquiriram grande importância. Fósseis de conchas marinhas encontrados nas montanhas eram utilizados como evidências da catástrofe por muitos naturalistas. Cabe aqui o registro de que, no sentido medieval e renascentista, fóssil significa apenas “enterrado”. Algo que foi retirado do solo ou das rochas. Algo que Deus incluiu no solo ou nas rochas durante a criação da natureza. Concreções, cristais, veios cimentados e vestígios de vida passada (conchas de moluscos, carapaças de artrópodes e de equinodermos, ossos e lenho) fazem parte de acervos de fósseis coletados durante a Idade Média e Renascimento. No seu sentido moderno, estabelecido ao longo do século XVII, fósseis são vestígios de vida passada (Rudwick 1976 apresenta uma extensa e muito bem elaborada evolução do conceito de “fóssil” desde o renascimento, dando especial destaque aos naturalistas do século XVII). Dois pontos devem ser ressaltados para toda a discussão acerca dos fósseis. No livro do Gênesis está afirmado que Deus separou a terra do mar no terceiro dia e criou a vida aquática somente no quinto dia. Como consequência, organismos marinhos não podem ser encontrados em terra. Também, como Noé levou um casal de cada "espécie”, não tem sentido discutir a possibilidade da existência, no passado, de seres diferentes dos atuais. Estas questões, nem sempre expressas, exerceram enorme pressão nos debates sobre a natureza orgânica $\mathrm{x}$ inorgânica dos fósseis até o início do século XIX.

Robert Plot (1640-1696), professor de química da Universidade de Oxford, agrega elementos importantes sobre os diferentes modos de pensar os fósseis na segunda metade do século XVII. Ele rejeitava a ideia de que impressões de conchas fósseis fossem vestígios de organismos antigos, pensava que eram cristais minerais ou urina congelada, e sua aparência com seres vivos apenas coincidência. Plot era um colecionador de fósseis e em 1677 publicou um livro intitulado "The natural history of Oxfordshire”, onde incluiu várias estampas com magníficos desenhos dos objetos de sua coleção. Ali estão apresentados desde conchas de moluscos e equinodermos, restos de corais e de ostras e um osso de dinossauro, até cristais de gipsita, seixos diversos e espinhos. Mas o notável da coleção é a forma de organização: pedras relacionadas a corpos etéreos ou ao ar, pedras pertencentes ao reino aquoso, pedras relacionadas à plantas ou animais e pedras lembrando partes de animais ou partes do homem (Plot 1677). Na primeira estampa, muitas impressões de equinodermes apresentam estruturas que lembram a representação usual das estrelas (com cinco pontas). Em duas outras estampas, uma composta quase que só por impressões de moluscos bivalves e outra por amonoides, equinodermos e bivalves, a perfeição do material torna a relação com o reino aquoso bastante óbvia (Fig. 1). Na última, uma concreção tem extraordinária semelhança com um coração e outra com um pé humanos. Inserido no modo de pensar a natureza de sua época, Plot coletava objetos por sua semelhança com estrelas, animais, plantas e partes do corpo humano.

Robert Plot fornece ainda outro exemplo de formas de raciocinar sobre a natureza dos fósseis. Ele
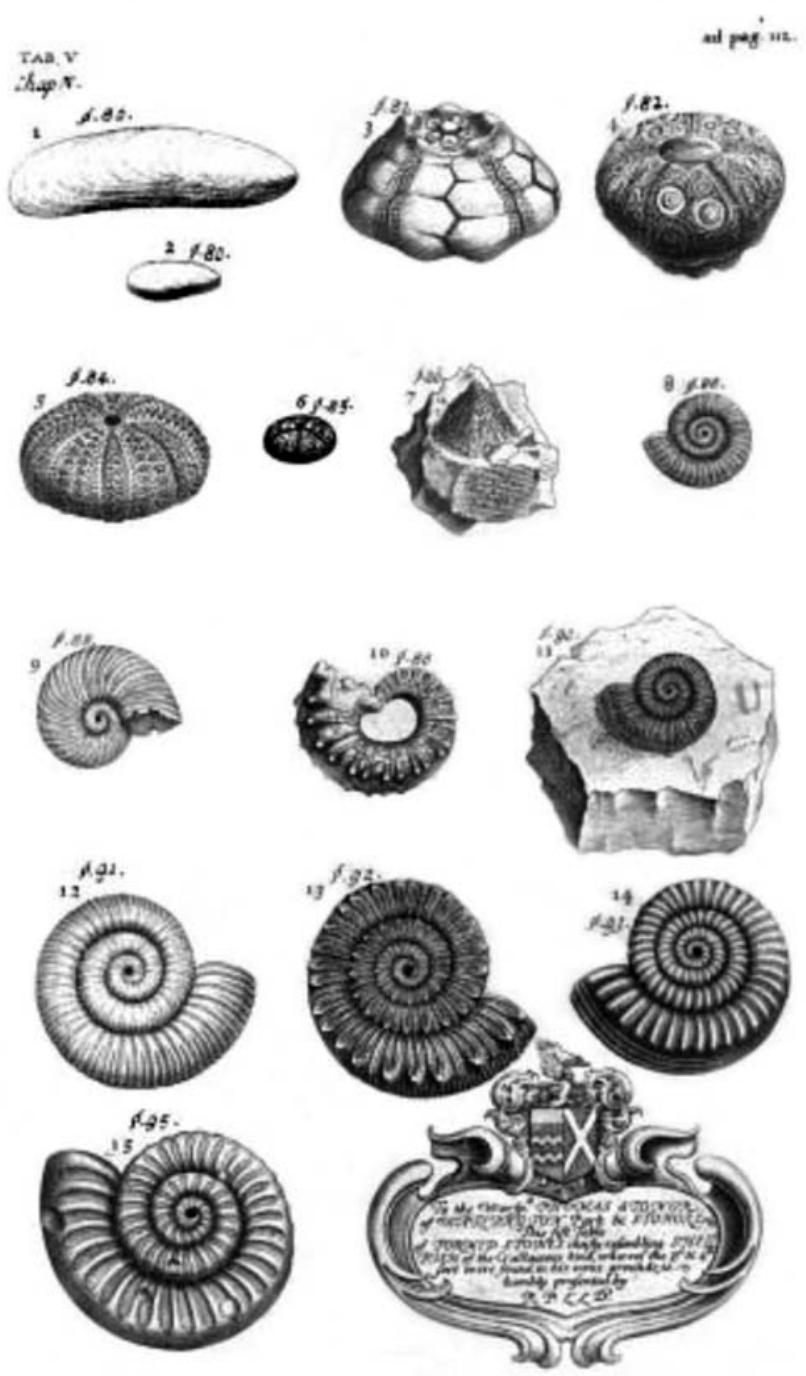

Figura 1 - Estampa contendo fósseis relacionados ao reino aquoso (Plot 1677). É importante ressaltar que Plot não admitia a possibilidade de serem vestígios de organismos antigos. Pensava que eram cristais minerais ou urina congelada. 
coletou e descreveu algo que, em sua opinião, se tratava de parte de um osso gigantesco. Embora petrificado, a forma, a presença da cavidade medular e da formação esponjosa interna permitiam a inferência. O grande tamanho sugeria um animal muito maior do que um boi ou um cavalo. Considerou-o como osso de elefante trazido pelos romanos durante a invasão das ilhas britânicas, a despeito de qualquer registro histórico que suportasse a hipótese (Plot 1677; p. 136). A oportunidade de compará-lo com ossos de elefante surgiu em 1676, quando um esqueleto foi levado para Oxford. Plot não teve dúvidas, o osso, além de muito maior, era totalmente diferente. Como hipótese final, considerou-o como pertencente a um gigante humano já desaparecido (Fig. 2; Plot 1677, p. 137). Em 1763, o naturalista Richard Brooks reestudou o fragmento e o batizou com o sugestivo nome de Scrotum humanum (hoje, este fragmento ósseo é considerado pertencente à parte distal do fêmur de Megalosaurus, um dos primeiros dinossauros descritos, antes mesmo da palavra "dinossauro" haver sido criada) (Halstead \& Sarjeant 1993).

Uma fase mais sofisticada da Paleontologia incipiente iniciou com Nicolas Steno. Anatomista brilhante, antes de se interessar por fósseis e rochas publicou trabalho mostrando que os animais também tinham glândula pineal e, portanto, ela não poderia estar associada com a natureza espiritual humana. Também desenvolveu estudo sobre músculos e experimentos sobre circulação do sangue, e foi o primeiro a demonstrar que o coração consiste de duas bombas relativamente independentes (Lamont 2001). Foi a partir dos trabalhos como anatomista que se interessou por rochas e fósseis, e acreditava que os fósseis eram restos de organismos desaparecidos. Dissecando um grande tubarão, Steno percebeu que seus dentes eram muito semelhantes a fósseis conhecidos como "língua de pedra” (glossopetrae), popularmente considerados como

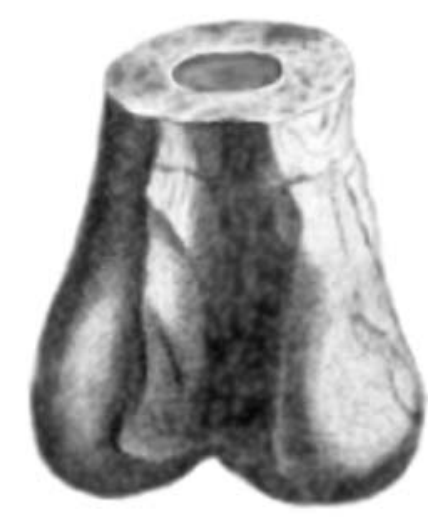

Figura 2 - Ilustração do fragmento de "Scrotum humanum” (gigante desaparecido; Plot 1677). cobras petrificadas ou línguas de dragão. Por comparação concluiu que os glossapetrae eram dentes de tubarão (Steno 1667). Steno acreditava que todos os fósseis marinhos foram transportados para as posições atuais durante o Dilúvio (Steno 1669; p. 258).

Um passo importante para a compreensão dos fósseis foi dado por Robert Hooke (1635-1703). Em 1668, com o auxílio do microscópio, o naturalista mostrou que alguns fósseis eram restos mineralizados de árvores e de moluscos (amonoides e nautiloides). Ele também não admitia que os fósseis pudessem ser organismos diferentes das espécies atuais (que houvessem sido extintos durante o Dilúvio), pois o mar profundo ainda era praticamente desconhecido. Pensava que a extinção de espécies diminuía a sabedoria e a onipotência do Criador (Halsall 1998). Ao longo de quase trinta anos (1668 a 1697), Hooke proferiu vários "discursos sobre terremotos", muitos dos quais reunidos em uma publicação após a sua morte (Hooke 1705). Em sua opinião, os terremotos são os principais modeladores do relevo terrestre. Nos "discursos", demonstrava inconformidade com a redução de todas as questões envolvendo regiões elevadas e fósseis ao Dilúvio. Para ele, as conchas e restos de peixes fósseis encontrados no topo dos Alpes, Cáucaso, Andes e Apeninos não tinham relação com o Dilúvio de Noé, mas sim com os terremotos que soergueram estes antigos leitos do mar (p. 319-321). Tinha convicção de que as terras contendo conchas fósseis foram formadas sob a água, em um tempo de inundação muito mais longo que o do Dilúvio (que durou menos de um ano), pois alguns organismos marinhos demoram vários anos para atingir o estado adulto (Hooke 1705; p. 341).

John Woodward (1665-1728) estava convicto de que fósseis eram "restos do Dilúvio Universal”. Percebia que diferentes camadas continham fósseis distintos. Para justificar, imaginou que, no Dilúvio, rochas e minerais foram erosionados (Woodward 1695; p. 85 - dissolution no original). Ao final do Dilúvio, começaram a se depositar cada uma de acordo com seu peso específico. Deste modo, as conchas mais pesadas se juntaram ao calcário e desceram primeiro. As carapaças dos ouriços do mar, mais leves, flutuaram algum tempo e se depositaram acima do calcário. Por fim, os fragmentos mais leves, como as carapaças das lagostas e galhos de árvores, formaram a camada superior. Deste modo, se formaram camadas planas como as de uma cebola (p. 90-91). Porém, não ficariam assim: ao final do Dilúvio, as forças internas da Terra produziram a maior e mais terrível catástrofe da história da humanidade (p. 93). A terra foi fragmentada em um monte de ruínas, formando montanhas (camadas que se ergueram a grandes alturas), colinas (camadas que se curvaram) e vales e o "canal do mar" (camadas que afundaram em depressões) (Woodward 1695). 
A partir de uma notável e exaustiva argumentação, John Ray considerou os fósseis de conchas e peixes como vestígios de antigos seres. Além dos critérios usuais da semelhança morfológica e detalhes de ornamentação, discutia outras questões, como o fato objetivo de, além de fósseis, conchas e restos de peixes não fossilizados serem encontrados em locais distantes do mar e mesmo em montanhas (Ray 1692; p. 107, 130 e 132). Utilizou este argumento para demonstrar a irrealidade da conclusão de que os fósseis podem ser gerados por cristalização de sais, tal com sugerido por Plot (p. 104 a 120). Na terceira edição do livro ("Three physico-theological discourses"), publicada apenas após sua morte, Ray (1713) ampliou a discussão sobre fósseis, incluindo as opiniões de Steno, Scilla e Woodward. Concluiu que as conchas e ossos de peixes dispostos na superfície, longe do mar, são reais e resultado do Dilúvio (e.g. p. 170). A partir da análise de Woodward (1695), discutiu os fósseis existentes nos estratos mais profundos, inclusos em camadas de areia e cascalho cimentadas (rocha), concluindo que não devem ser atribuídos ao Dilúvio (p. 171). Mas discordou da opinião de Woodward sobre a redeposição de sedimentos a partir da gravidade específica, pois percebeu que sedimentos pesados e leves (cascalho e argila) são muitas vezes encontrados no mesmo estrato (Ray 1713; p. 170-171).

Cabe registrar que Ray incluiu nos "três discursos", uma longa carta enviada em 1698 por Edward Lhwyd (1660-1709), onde este retoma os argumentos de Robert Plot e conclui que os fósseis não podem ser considerados como restos de organismos antigos (p. 175-203). Com relação aos fósseis e o Dilúvio, Lhwyd relaciona, de modo minucioso, várias evidências em contrário, tais como os fósseis serem por vezes encontrados em rocha sólida e a grandes profundidades, e não na superfície e em sedimentos, como deveria ser o caso. Ray concorda com os argumentos de Lhwyd de que os fósseis na rocha sólida não devem ser relacionados ao Dilúvio (p. 203), mas, em seguida, reafirma a convicção que são vestígios de conchas e ossos de peixes (Ray 1713; p. 204).

Como estudioso das escrituras sagradas, John Ray percebeu com clareza o problema terrível dos fósseis com relação ao Dilúvio. Ele sabia que existiam fósseis de espécies desconhecidas contidos nas rochas profundas. Como o Dilúvio durou menos de um ano, estas espécies não poderiam descender das que Noé salvara. Esta era uma heresia para a qual ele não se encontrava preparado. Na primeira edição dos “miscellaneous discourses”, Ray (1692) se esquiva das consequências de sua argumentação, mudando a discussão para a formação de montanhas a partir do fogo subterrâneo. Na terceira edição (três discursos), ele questiona se não está contribuindo para o descrédito na idealização do Dilúvio Universal: “... colocando uma arma em mãos ateístas” (Ray 1713; p. 168).

Sem atentar para conflitos com textos sagrados, o pintor siciliano Agostino Scilla (1629-1700) publicou trabalho sobre fósseis marinhos da Calábria. Deixou clara sua incredulidade contra os que não aceitavam a natureza orgânica dos fósseis, pois se constituíam na prova definitiva do Dilúvio Universal (Scilla 1670). Ao final do livro, estampas notáveis representam fósseis de moluscos, equinodermes, corais e mandíbulas e dentes de tubarões.

Além de matemático e filósofo, Gottfried Leibnitz também trabalhou como engenheiro de minas na região de Harz, na Alemanha, e entre 1691 e 1693, desenvolveu algumas ideias sobre a origem e evolução da Terra. Elas apareceram em vários momentos, em conversas e cartas dirigidas a amigos, mas foram integralmente conhecidas somente após sua morte, quando da publicação do livro "Protogaea" em 1749. Cabe destaque a clara ideia dos fósseis como evidência de seres antigos. Indo além, afirmou que, quando o oceano cobria tudo, os animais eram aquáticos, conforme as águas se retiravam, tornaram-se pouco a pouco anfíbios até seus descendentes abandonarem em definitivo a antiga morada. Quanto à petrificação, pensava ser processo muito lento, pois a natureza não facilita saltos (Leibnitz 1749). Leibnitz também descreveu fósseis interpretados como ossos, considerando-os como pertencentes a um unicórnio. Após um breve exame das características anatômicas, apresentou sua reconstituição (Fig. 3) (hoje identificados como dentes molares, presas e ossos de mamute).

Os fragmentos extraídos da literatura do século XVII são bastante reveladores. Muitos sábios estudavam estratos sedimentares, fósseis, montanhas, e estabeleceram hipóteses para explicar o que viam. Hipóteses muitas vezes absolutamente corretas no seu contexto. Os primeiros passos para vários princípios básicos que poderiam nuclear uma futura ciência geológica estavam sendo formulados, direcionados para tornar científico o Dilúvio bíblico. Mesmo as hipóteses relacionando causas exógenas, como a do cometa, por Whiston, ou a aproximação com a Lua, citada por Leibnitz, sua base não era mais a adivinhação, era a nova astronomia e a gravitação universal, havia muitos cálculos precisos e princípios científicos utilizados com rigor.

Vamos tentar compreender, agora, como foi possível a transformação na visão de mundo dos homens cultos.

\section{A EPISTEME CLÁSSICA E A TRANSIÇÃO DO PENSAMENTO MEDIEVAL E RENASCENTIS- TA AO PENSAMENTO MODERNO No mundo}


criacionista, Deus era a Suprema Causa Final. A Terra era uma implicação natural do ato da Criação. Deus criou o mundo em seis dias e, deste modo, mares, montanhas e toda a paisagem, todos os seres vivos, surgiram na mesma semana. É evidente que "evolução” não é possível, seja a transformação das espécies ou o fundo do mar virar montanha. Além disso, e de fundamental importância, não havia a percepção de que a linguagem é um produto humano (Foucault 1985). As palavras e as coisas que elas representam eram ligadas por uma origem comum, o ato da criação (Cassirer 1925). Deus criou o homem e deu-lhe uma linguagem, e esta, portanto, não podia ser um sistema arbitrário ou mutante. Neste sistema, a linguagem se encontrava incorporada à natureza, estava sedimentada no mundo, e as palavras tinham as mesmas propriedades das coisas que nomeavam. Não era possível “descrever” um fenômeno natural a partir da análise,

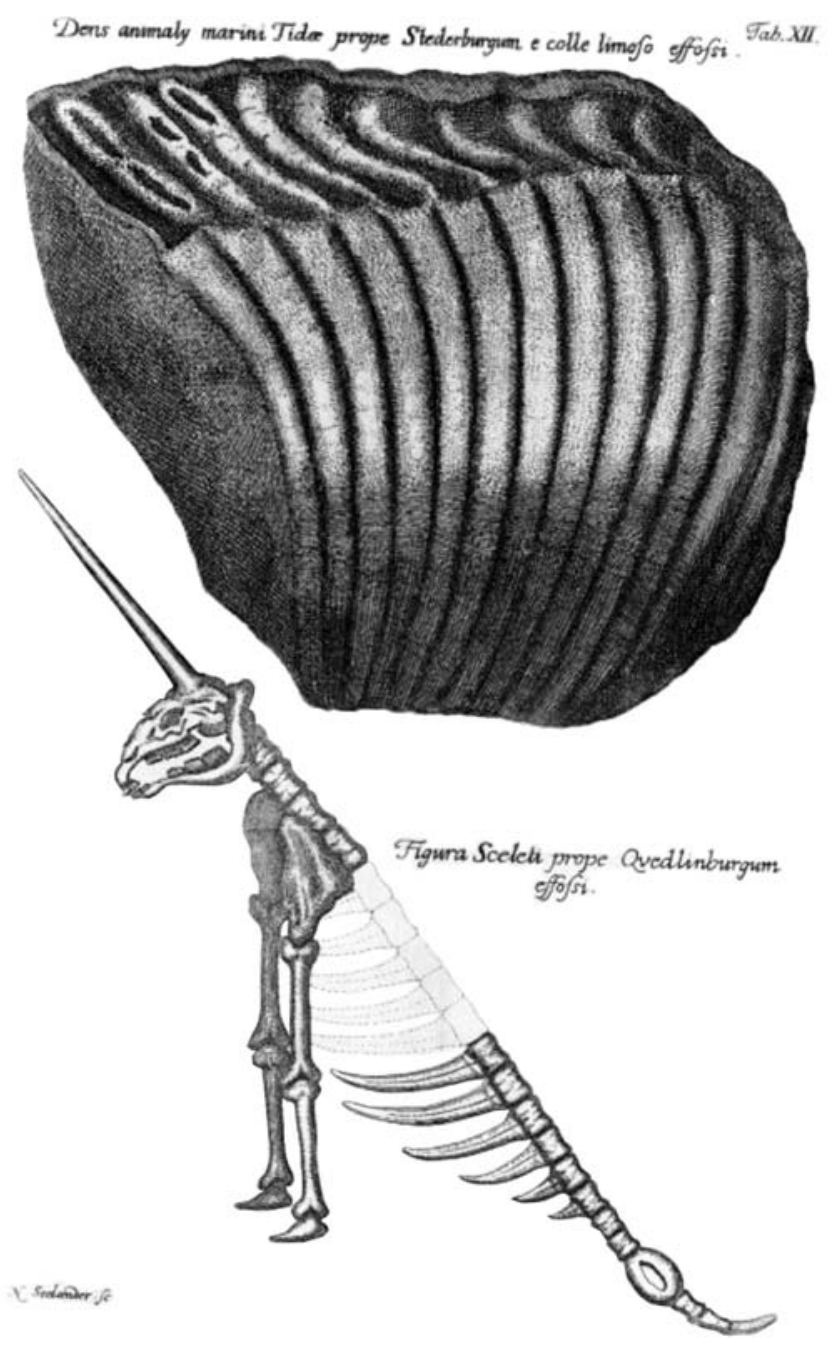

Figura 3 - Dente molar e reconstituição do Unicórnio (Leibnitz 1749). da ordenação das ideias, tal como vai ocorrer a partir da segunda metade do século XVII. As palavras estavam ligadas de modo absoluto às coisas do mundo, carregadas demais de sentido, densas demais para permitir isso (Foucault 1985).

Analogia No século XVI, a semelhança organizava o saber da cultura ocidental (Foucault 1985). A explicação de algo, o saber, era feito por analogia: revelar aquilo que é parecido, descobrir aquilo que é semelhante. E a similitude só pode ser reconhecida porque, no mundo, existe um número imenso de marcas (sinais), deixadas pelo Criador. Uma similitude não visível, oculta no interior das coisas, tem que estar assinalada em sua superfície (Foucault 1985). A catapora é uma doença interna, mas deixa marcas na pele, signos colocados por Deus que permitem sua identificação; a chuva é prenunciada pelo aparecimento de certo tipo de nuvens (signo da chuva). A semelhança une as coisas do mundo por meio de parentesco e analogia (marcas, sinais particulares). Expresso de outro modo, observação e imaginação possuem o mesmo status, estão colocadas no mesmo plano (Pernold 1997).

Como exemplo simples das diferenças entre esse modo de pensar e o moderno, podemos comparar as asas da borboleta e do pássaro e o braço humano. Para um modo de pensar que aproxima coisas, existe uma analogia evidente quanto às asas (assinalam o voo) $\mathrm{e}$ nenhuma semelhança quanto ao braço. Porém, do ponto de vista anatômico, depois de estabelecidas relações estruturais, de tecidos e de ordenamento taxonômico, as diferenças entre as asas da borboleta e do pássaro tornam-se imensas. Com relação à asa do pássaro e o braço humano, tudo é uma questão de função, são estruturas homólogas (têm uma origem comum). Os ossos que compõem a asa do pássaro adquiriram desenvolvimento diferente, mas estão todos lá, mesmo os ossos do carpo e falanges, que no pássaro estão alongados e unidos para aumentar a envergadura e resistência mecânica durante o voo.

Paracelso (1493-1541) criou uma "receita" na qual o metal mercúrio tem o poder de curar a sífilis (utilizada durante três séculos). Sua argumentação mostra que a sífilis provém do (está assinalada pelo) comércio do sexo (prostituição). O planeta Mercúrio, desde a mitologia grega, sempre foi associado (assinalado) ao comércio. Portanto, o metal mercúrio, que possui o mesmo nome, tem o poder de curar a sífilis (Hacking 1995). A conclusão foi possível porque existia uma ligação forte entre as palavras em si, e as palavras com as coisas. As semelhanças, no caso de Paracelso, estão ocultas, foi necessário um raciocínio para ligá-las, uma evidência que procura semelhanças ocultas entre as coisas (Zir 2005, Pernold 1997). 
Na segunda metade do século XVII, o conhecimento fundamentado na aproximação das coisas entre si é substituído por outro, onde é necessário discernir, ordenar, estabelecer identidades e buscar as diferenças (episteme clássica; Foucault 1985, p. 76). Mas a mudança, embora rápida, não foi instantânea, e a similitude ainda se manteve até o final do século disputando espaço com o novo pensamento analítico. Robert Plot, o colecionador de fósseis, ainda pensa a natureza em termos de similitudes. Os critérios de classificação revelam um modo de pensar por analogia, identificar e mostrar as semelhanças entre os objetos (colecionava afinidades). Suas estampas assinalam um parentesco, ou uma atração, entre coisas desenterradas (fósseis em seu sentido amplo) e coisas do céu, do mar e da terra. Por esta razão não cogitava que as magníficas impressões de moluscos, equinodermes e outros animais de sua coleção fossem evidências de seres antigos.

Aqui se delineia uma questão interessante com relação a Plot: a interpretação do osso petrificado e o raciocínio desenvolvido. Seria um indício de pensamento científico em uma mente ainda dirigida pelo pensamento criacionista? Provavelmente não. A natureza do raciocínio, com encadeamento de evidências e formulação de uma hipótese, depois testada e falseada, seguido pela formulação de uma nova hipótese, sugere pensamento analítico moderno. Mas Plot pensou, inicialmente, que deveria ser o osso de um elefante do ano cinquenta da nossa era, o que não causaria conflito com o Dilúvio (o fato de ter se tornado pedra talvez pudesse ser colocado como um problema menor, a ser explicado de modo semelhante à cristalização da urina). Quando percebeu, por análise de ossos de elefante, que esta comparação não era possível, rejeitou a ideia. Neste momento, criou outra hipótese, fundamentada ainda no critério da semelhança. Por detrás da rápida mudança, está a questão do Dilúvio. Manter a ideia de que era parte de um fêmur implicaria, em essência, afirmar o desaparecimento de espécies. Como a Bíblia se referia a gigantes humanos, e à época existiam muitas lendas sobre sua existência no passado e mesmo estudos técnicos de ossadas (e.g. trabalho de Athanasius Kircher; Palmer 2005), o desaparecimento foi posterior ao Dilúvio. E o desenho do "Scrotum humanum" foi incluído na estampa referente a "pedras que se relacionam a partes do homem ou coisas do ar". Plot jamais cogitou a possibilidade de seu "osso" ser atribuível a uma espécie diferente das atuais.

A análise da literatura referente ao Dilúvio Universal durante o século XVII revela a existência de muitas contradições, a começar pela discussão da natureza orgânica ou mineral dos fósseis. Apesar do que se possa pensar num primeiro olhar, não estão em oposição, os fósseis não foram utilizados no sentido de uma contestação, ou uma negação do pensamento cristão.
Nasceram de uma mesma formação discursiva. Constituíram aquilo que Foucault (1997) delimita como “contradições arqueologicamente derivadas". Embora contrárias, nasceram de um mesmo ponto e nas mesmas condições, derivaram de uma única e mesma positividade: o Dilúvio bíblico. Em verdade, era um apoio incondicional; o que estava em jogo era a tentativa, de homens crentes e sinceros, em provar a veracidade da Bíblia, de tornar científico o Dilúvio Universal, jamais destruí-lo ou colocá-lo em outros termos.

\section{A dualidade (ou a continuidade) entre a ciência e a}

fé Burtt (1983) chama a atenção para as inconsistências técnicas e filosóficas dos textos de grandes expoentes do alvor da ciência. Uma confusão de crenças religiosas, crendices populares e mitologias, mescladas com informações teóricas ou técnicas importantes. Por vezes, apenas a fé religiosa fundamentaria um fato científico interpretado de modo correto. Em um momento, Burtt (1983) declara-se desapontado com o texto de Newton: "Somente um punhado de declarações gerais e muitas vezes vagas a respeito do seu método, que requerem trabalhosas interpretações...”. Também afirma que os participantes mais importantes do processo de criação da ciência moderna não tinham clara noção do caminho que estavam seguindo (Burtt 1983, p. 168). Em verdade, está apenas evidenciando o abismo que se estabeleceu nestes pouco mais de 300 anos, com relação ao pensamento criacionista.

Ao longo do século XVII ocorreu extraordinária transformação na visão de mundo dos homens cultos. Houve a eliminação de quase todo o animismo das leis físicas (Feynman 2001), e isto teve implicações importantes, pois desde os gregos antigos, o movimento necessitava de um motor e era ligado à vida, era um sinal de vida. A partir de Copérnico, o homem foi deslocado do centro do Universo, a Terra era apenas mais um dos planetas. Além disso, Kepler, ao provar que a órbita da Terra não era circular, destruiu a idealização dos corpos celestiais perfeitos de Pitágoras. Galileu exibiu ponto a ponto os erros da física aristotélica, e isso tinha muitas implicações, pois era a física do senso comum, da percepção imediata dos sentidos, e a substituiu por uma física expressa em linguagem matemática, de difícil compreensão (e que permitia concluir que o observado nem sempre é real) (Koyré 1986). Finalmente Newton, que ao agregar a matemática ao experimento, definiu as leis precisas que governam os fenômenos físicos, retirando a necessidade da intervenção do Criador (Russell 1982, Burtt 1983). Para Newton (1704), o experimento é uma pergunta feita à natureza em linguagem geométrica e matemática.

O cientista do século XVII apresenta uma dualidade, ele utiliza raciocínios e parâmetros científicos, 
mas ainda é um religioso convicto na veracidade das Escrituras. Em algum momento havia um conflito com as crenças e, na maior parte das vezes, a compatibilização das hipóteses científicas com a religião era difícil - e não era aceita pela Igreja nem pelas pessoas comuns, muito marcadas pela criação religiosa. Francis Bacon separava a fé da razão, não negava que o curso da natureza revela uma finalidade divina, mas não aceitava a explicação teológica na investigação verdadeira dos fenômenos (Bacon 1620). Como não percebia a importância da dedução matemática, rejeitou Copérnico (Fiker 1996). Já René Descartes considerava a dedução matemática como a chave para o conhecimento (Koyré 1992). Católico sincero, desejava persuadir a Igreja a ser menos hostil com a ciência, afinal, Deus era a origem de tudo (Descartes 1637).

A alteração na forma de percepção da natureza acompanhou uma mudança gradual em termos sociais. A ascensão da burguesia e a mudança nas relações de poder, a diminuição do poder da Igreja e o enfraquecimento progressivo da conotação divina das palavras e de sua relação visceral com os objetos do mundo criou espaço para a transformação do pensamento (Foucault 1985, 1998). A redução do peso da autoridade da Igreja passou por ações como a de Spinoza, primeiro a conceber a ideia de uma historicidade na Bíblia. Spinoza mostrou que a Bíblia é uma realidade condicionada ao tempo, uma coleção de conceitos antropomórficos e, desse modo, não faz parte do domínio da verdade filosófica. A imagem de Deus fica vinculada à subjetividade do profeta que, pretendendo falar em nome de Deus, fala apenas em seu próprio nome (Cassirer 1992). Também, quando Richard Simon (1638-1712) examinou os diversos livros da Bíblia quanto à origem e autenticidade, os fundamentos da ortodoxia foram abalados (Cassirer 1992). Não foi uma ação contrária à Igreja, o objetivo era atacar os protestantes, demonstrar que não deveriam confiar demasiado na verdade bíblica (Lutero havia dito que a Bíblia é a autoridade suprema e final, ficando acima da autoridade da Igreja).

A reação mais forte da Igreja aconteceu na Itália, onde a inquisição condenou a ciência ao silêncio. Galileu foi condenado em 1616 e em 1633, quando se retratou. Para Cassirer (1992), ao contrário do que se pensa, a Igreja permitia discutir o heliocentrismo enquanto hipótese matemática, mas considerava inaceitável a nova concepção de verdade que Galileu proclamava, que não tinha por base a Revelação ou o testemunho das Escrituras. Nos países protestantes não ocorreram perseguições, simplesmente porque a Igreja não dominava o Estado.

Em sintonia com a Física e Matemática, o direcionamento para a história natural de rochas e fósseis, no século XVII, só foi possível porque praticado por pessoas que, em sua total sinceridade, esperavam encontrar as evidências dos eventos naturais descritos na Bíblia. O Dilúvio, por sua extraordinária importância, o principal evento bíblico depois da criação, teria, segundo alguns, de ter deixado evidências. Procurá-las, descrevê-las, não seria heresia, por si só; ao contrário, permitiria melhor compreensão do modo como Deus criou o mundo.

\section{O pensamento analítico e a expulsão de Deus do} mundo natural A segunda metade do século XVII marcou uma grande mudança no modo de pensar a natureza. Não se buscava mais compreender a "ordem do mundo", mas se procurava estabelecer as identidades e as diferenças entre as coisas do mundo. O pensamento analítico permitiu que cada pessoa culta pudesse efetuar recortes da natureza, e analisá-los segundo suas conveniências. Neste momento, como mostrou Foucault (1985), surgiu o espaço para as ciências naturais. Neste espaço, Galileu, Newton, Burnet, Ray e muitos outros mostraram como estabelecer relações totalmente novas entre as coisas da natureza.

Em menos de cinquenta anos, a natureza deixou de ser uma coleção de substâncias ou depósito misterioso de forças incalculáveis e tornou-se um sistema de leis mecânicas, mundo da matéria e do movimento (Robert Boyle). Um Universo máquina/mecânico com corpos que se movimentam no espaço e no tempo (Isaac Barrow, 1630-1677) e que se manteria em funcionamento mesmo que não existissem seres humanos (René Descartes). Mas, ressalta Boyle, a presença de Deus é de suma importância neste Universo, pois, sem as forças de coesão espirituais ele se desintegraria (Russell 1982, Koyré 1961, Burtt 1983) (o Universo era concebido como mecanismo, em boa parte, em função do grande salto tecnológico por detrás do aumento na precisão do relógio). O século XVII estava tentando construir um Universo que poderia ser descrito por equações matemáticas: "Os princípios matemáticos e mecânicos são o alfabeto com que Deus escreveu o mundo" (Robert Boyle; in: Russell 1982); Deus escreveu "... o livro da natureza em linguagem matemática” (Galileu Galilei 1623); “... a Geometria foi a única ciência que, com satisfação, Deus ensinou à criatura humana" (Hobbes 1651; p.36). "A Terra foi formada de acordo com as conhecidas leis do mecanicismo. ... Ele [Deus] pôs facilmente a Máquina [Universo] em movimento, sem a necessidade de correções ou ajustes” (Whiston 1696; p. 303 e 435); “... eu não tenho vergonha de minha perplexidade, e me acalmo sempre que faço reflexões sobre a hipótese da grande máquina do Universo" (Scilla 1670; p. 37).

A visão de Deus como relojoeiro com a função primeira de "dar corda" ao grande relógio universal 
está em sintonia com o pensamento de Pitágoras ( 569475 a.C.), segundo o qual "todas as coisas são números" (Rutherford 1991). O modelo heliocêntrico de Copérnico e Kepler, por exemplo, encontra-se inserido no pensamento pitagórico da Baixa Idade Média, que defendia a harmonia geométrica simples do Universo (Sá 1944). Todos os elementos têm proporções matemáticas, pois "o número é o primeiro modelo das coisas na mente do Criador" (Nicolau de Cusa, 14011464; in: Burtt 1983). Copérnico e Kepler acreditavam que o Sol, por fornecer luz e calor necessários à vida, é a emanação visível de Deus. Deste modo, o modelo heliocêntrico seria mais harmonioso, por colocar o Criador no centro do Universo (Koyré 1982, Burtt 1983). Kepler foi explícito quanto à sua real motivação para defender o heliocentrismo (Burtt 1983).

Ao longo do século XVII, não havia mais a necessidade objetiva de um Deus como causa para os fenômenos imediatos. Ainda era necessário Deus para dar início aos processos, mas, mesmo assim, todo esse novo sistema teórico gerava desconforto aos teólogos (Burtt 1983). A súbita expansão do Universo tornou o homem muito pequeno, e o Criador tinha, agora, que administrar um Universo tão vasto que teria pouco tempo para o homem (Russell 1982). Especialmente com Galileu e Descartes, o homem perdeu seu lugar de destaque e passou a ser secundário, um espectador irrelevante do mundo real (Burtt 1983).

Na segunda metade do século XVII, os homens cultos estavam se afastando das causas finais, substituídas pela inferência de causas a partir do experimento, causas eficientes, que explicam como as coisas funcionam. Newton definiu no prefácio do Principia o seu recorte: "investigar as forças da natureza a partir dos fenômenos de movimento e, dessas forças, demonstrar os outros fenômenos". Um recorte preciso, explorado de modo experimental e expresso em linguagem matemática. Whiston, Burnet, Ray e Woodward reconstruíram o Dilúvio considerando apenas "causas físicas $e$ mecânicas", sem a introdução de "milagres de natureza precária” (e.g. Burnet 1691, Whiston 1696). Para Foucault (1985), é justamente este distanciamento, esta separação, que define a episteme clássica. Até meados do século XVII, descrever um fenômeno englobava tudo o que havia para ser dito, incluindo lendas, fábulas e as opiniões em sua diversidade. A reconstrução do Dilúvio Universal no século XVII levava em conta, na medida do possível, apenas aspectos físicos: opiniões e milagres foram excluídos da discussão técnica.

A natureza estava deixando de ser passiva, mas não prestava testemunho de modo espontâneo, passava a esconder segredos, e o método generalizado por Francis Bacon foi buscar, nas práticas processuais do inquérito judicial medieval (Foucault 1998, 1999b), sua inspiração: o cientista deve “...torturar a natureza como faz o inquisidor com o inquirido, até que ela entregue todos os seus segredos. A natureza das coisas revela-se muito mais quando maltratada do que quando deixada em liberdade" (Bacon 1620) (uma discussão mais elaborada do início do método científico é encontrada em Lavina 2004).

Ao longo dos séculos XVII e XVIII, as tentativas dos homens cultos de procurar evidências, relações de causa-efeito sobre acontecimentos e fenômenos físicos permitiu a reunião de particulares em associações, ou, de outro modo, das evidências particulares para a formulação de princípios gerais (leis). A indução passou a ser possível porque as palavras foram perdendo densidade, tornando-se um instrumento para o desenvolvimento de ideias, para a descrição dos fenômenos naturais (Foucault 1985).

Por caminho diferente de Galileu, Newton e Descartes, os sábios que procuravam explicar o Dilúvio também criavam imensas dificuldades aos teólogos. Com Newton, sabia-se, Deus criou o Universo, colocou a Terra e os corpos celestes em movimento, e não mais interferiu. Na visão dos naturalistas, Deus criou a Terra inicialmente plana e posteriormente o Dilúvio, mas oceanos e continentes, montanhas, vales e toda a paisagem, se desenvolveram sem a Sua intervenção.

A consequência radical da mudança foi que o somatório, a integração das conclusões, explícitas ou implícitas, nas contribuições individuais dos pesquisadores, ocasionou a "expulsão" de Deus do mundo natural. Cada sábio focalizava o seu olhar em um detalhe da natureza, e naquele ponto, suas explicações uniam causas e efeitos imediatos, que prescindiam da presença do Criador. Vistas em separado, não havia problema, e cada estudioso se sentia confortável em expressar seus resultados (e muitos protestavam contra as opiniões de que suas teorias contradiziam a Bíblia; e.g. Copérnico, Galileu e Burnet). Ainda assim, os teólogos sentiam-se inquietos, pois as novidades deslocavam a participação de Deus da história da natureza, dos corpos celestes e, mais importante ainda, do homem. Quando vistas em conjunto, e esta era a função da Igreja e dos teólogos, o resultado foi a súbita exclusão de Deus dos fenômenos naturais, Sua presença ativa no mundo passou a não ser mais necessária. De Suprema Causa Final, Ele passa a ser o Criador dos átomos ou a Primeira Causa Eficiente do mundo (Isaac Barrow) (Burtt 1983, Koyré 1961). O iniciador dos processos naturais (e.g. dilúvio, movimento dos planetas) que, depois, seguem caminho independente. Um pouco mais adiante (1784), Immanuel Kant (1724-1804) irá sugerir que, se a história humana tem algum sentido, deve existir um plano secreto (princípio teleológico) que justifique e revele a importância futura dos conflitos e sofrimentos humanos (Gardner 1995). 
A importância do Dilúvio Universal na transição do pensamento renascentista ao pensamento moderno Os fósseis, em sua contradição intrínseca, delimitaram graves conflitos no interior da episteme da similitude. Os fósseis não eram aceitos pelos teólogos principalmente por não constarem das Escrituras. Porém, em muitos casos, à associação do fóssil a um ser, em especial impressões de conchas e carapaças, era muito evidente. Como afirmava Ray (1692), muitas apresentam o material original, não estando propriamente petrificadas. Conchas semelhantes a moluscos atuais no alto de montanhas produziam conflitos com as Escrituras, mesmo durante a Alta Idade Média (Gayrard-Vali 1994). Do ponto de vista do homem simples, a questão do Dilúvio e, principalmente, dos fósseis, era mais atraente e mais facilmente perceptível que as questões envolvendo a transição da Física medieval para a Física moderna. Galileu, Newton e Descartes colocavam o problema desde um ponto não atingível pelo leigo: expressar fenômenos naturais em linguagem matemática. Isto só era acessível aos homens cultos. Aos homens simples, muitas vezes enraizados nas inúmeras regiões montanhosas da Europa, uma concha fóssil era mais eficiente como disparador de conflitos com as Escrituras e com a oratória dos padres. Sua leitura é muito mais simples, a assinalação é direta.

Homens cultos como Burnet, Ray, Woodward, Steno e Leibnitz não se deixavam enganar, sabiam que as semelhanças eram reais. Os fósseis eram restos de organismos antigos e deveriam ser relacionados ao Dilúvio, esta era uma conclusão evidente ("O Dilúvio encheu os penhascos com os corpos dos animais sacrificados”; Burnet 1691). Além disso, Moisés, São Pedro e Santo Agostinho afirmaram que o Dilúvio foi natural. Burnet usou esta defesa ao ser acusado de “atacar as raízes da religião". Dizia que ao estudar o Dilúvio Universal, sua principal motivação era defender a Bíblia. Apoiava-se no pensamento de Bacon e Boyle, segundo os quais desenvolver a ciência era uma tarefa religiosa (Burtt 1983). Se o Dilúvio foi natural, pode ser analisado, detalhado e subdividido em eventos, desde a elevação das águas, morte dos seres e sua inclusão nos sedimentos, até a ruptura da crosta e a formação do canal do mar e das montanhas. Mas havia um problema maior: muitos sabiam que os fósseis das camadas mais profundas, mais antigas, eram diferentes dos atuais. O conflito com as Escrituras era evidente, e seguiu num crescente. A partir da reconstituição do "tubarão" de Steno, começam a surgir muitas hipóteses sobre a anatomia dos fósseis. Os resultados alcançados, apesar de na maior parte das vezes não serem significativos para o avanço da Paleontologia científica, causavam grandes discussões e controvérsias.
Num parênteses, cabe referir que os conflitos prosseguiram ao longo do século XVIII, pois a atenção estava cada vez mais direcionada à interpretação dos organismos que geraram fósseis. Em 1726, Johann Scheuchzer (1672-1733) causou sensação ao descrever o esqueleto do Homo diluvii testis, a testemunha do Dilúvio, o homem deixado por Noé (Fig. 4) (hoje uma salamandra fóssil; Prothero 2004). O grande momento, o surgimento luminoso da paleontologia científica deu-se ao final do século XVIII, quando "... Paris ficou chocada, interessada, incrédula, fascinada...” (Moore 1956) com a exposição de esqueletos fossilizados de mamutes, rinocerontes, hipopótamos, ursos e lobos, encontrados nos arredores da cidade. Realizando análise precisa e detalhada dos fósseis da Bacia de Paris, Georges Cuvier (1769-1832), apesar da fé absoluta no teor das Escrituras, apesar da certeza pessoal de que desenvolvia uma tarefa religiosa, desarticulou completamente a versão bíblica do Dilúvio (Moore 1956).

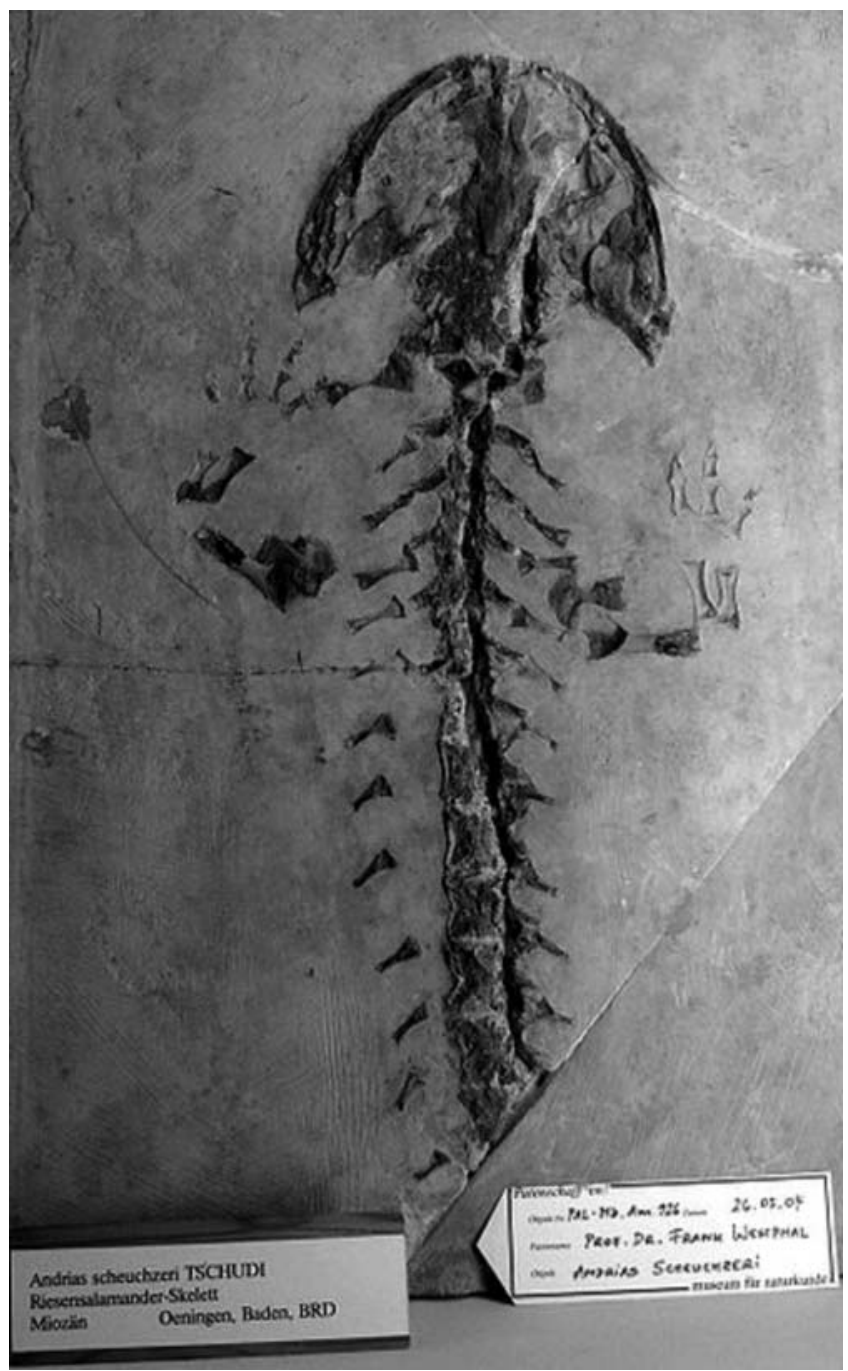

Figura 4 - Esqueleto do Homo diluvii testis de Johann Scheuchzer (Prothero 2004). 
A questão (da falta) do tempo Hoje, temos por base, em qualquer análise científica, o tempo cosmogônico (cerca de 13 bilhões de anos = $13 \mathrm{Ga}$ ) para situar inclusive eventos anteriores ao surgimento do Sol e da Terra, e o tempo geológico $(4,6 \mathrm{Ga})$ para posicionar os eventos da história da Terra (Patterson 1956, Dalrymple 1991). O tempo geológico é um (sub)produto da radioatividade, da estimativa de decaimento radiométrico (meia-vida) de alguns elementos químicos altamente instáveis. O tempo cosmogônico é uma consequência da constante de Hubble, que mede a taxa de espalhamento do Universo (indica a "velocidade" de afastamento entre as galáxias).

O tempo geológico e o tempo cosmogônico são produtos tecnológicos, não fazendo parte dos avanços da cultura teórica. Na passagem para o século XX, o físico de maior renome (Sir William Thomson), utilizando teorias aceitas como verdadeiras pela comunidade científica, afirmava, a partir de cálculos matemáticos precisos, que a Terra não poderia ser muito mais velha que 20 milhões de anos (= $20 \mathrm{Ma}$ ) (Wyllie 1979, Cullen 2006). Era contestado por muitos geólogos e alguns físicos e astrônomos, para os quais essa idade era insuficiente para distribuir os eventos geológicos. Arthur Holmes, geólogo e mais radical entusiasta da ideia da antiguidade da Terra, já utilizando taxas de decaimento radiativo, concluiu que a idade deveria ser de 1,6 Ga (Holmes 1913). As estimativas de Holmes eram questionadas mesmo pelos defensores da antiguidade da Terra, que postulavam, no máximo, algumas centenas de milhões de anos. Apesar das dificuldades, os avanços da ciência geológica foram expandindo a idade da Terra até o início da década de 1950, quando se atingiu um consenso em torno de 1,5 a 1,8 Ga. Esta estimativa estava em equilíbrio com a idade de cerca de $2 \mathrm{Ga}$, calculada para o big bang por Edwin Hubble, a partir da taxa de expansão do Universo (Hubble 1929). Porém, em 1956, quando Clair Patterson datou meteoritos (radiometria) e anunciou que a idade da Terra era de 4,6 Ga, toda a comunidade de cientistas foi tomada de surpresa (e.g. Moore 1956; p. 10, 308).

Deve ser ressaltado que a questão da idade da Terra, fundamental e decisiva na abordagem que estamos propondo, tende a passar despercebida nas análises históricas. Se o Dilúvio havia ocorrido há pouco mais de 4.000 anos, nenhum evento geológico poderia ser "lento e gradual" - não existe tempo para isso. Deste modo, o "catastrofismo" do século XVII, como sistema teórico, é absolutamente lógico e válido. A visão uniformitarista das transformações lentas e graduais, uma construção aperfeiçoada durante mais de 150 anos, não pode ser plenamente desenvolvida na ausência de um tempo geológico compatível.
Na segunda metade do século XVII já era possível pensar a transformação das coisas em outras coisas, mas a questão do tempo necessário para os eventos geológicos ficava sem solução. O Universo tornara-se subitamente, se não infinito, pelo menos imenso. Como o tempo disponível era muito pequeno, as transformações do mundo natural estavam aceleradas, afinal, para transformar fundo de mar em montanha na escala do tempo bíblico, é necessária uma catástrofe global.

Os naturalistas do século XVII não estavam mais vinculados à estagnação utópica da natureza estável da criação. Ao contrário, vivenciavam uma intensa aceleração devido à falta de tempo para distribuir os eventos geológicos. Percebiam eventos e conseguiam construir (ou intuir) sua sucessão, mas não era possível distribuí-la no tempo, simplesmente porque não havia tempo. O volume diário de meio oceano de água transportado pelos rios para o mar, calculado por Ray, se insere neste contexto. Ele necessitava modelar a paisagem e aplainar montanhas inteiras em poucos milhares de anos. Cabe destacar que mesmo a evolução das espécies de Darwin, um século depois, também estava muito acelerada - ao tempo de Darwin, os mais radicais opositores ao "tempo bíblico" especulavam valores inferiores a noventa milhões de anos. A insuficiência do tempo disponível só aparece como questão com Burnet e, de modo indireto, Leibnitz e Ray. No século XVII, e nos posteriores, muitas pessoas cultas colocavam a questão do tempo como objeção à visão das transformações geológicas. A não inclusão do tempo na discussão distorce a visão de mundo do século XVII, e permite conclusões criativas como a de William L. Stokes: "A mente humana é fascinada por cenas de violência e destruição, e esta atitude pode ter encorajado a se acreditar em catastrofismo" (Stokes 1960; p. 32).

A história natural dos fósseis e das rochas A tentativa de tornar científico o Dilúvio Universal possibilitou o desenvolvimento de um pensamento direcionado para rochas e fósseis. Princípios básicos como o da superposição e da horizontalidade original dos estratos sedimentares, ideias que hoje parecem absolutamente simples, foram conquistas grandiosas do século XVII. Sempre citados nos livros de Geologia Histórica, estes princípios são apresentados ligados à origem da estratigrafia (que só acontece no século XIX) e, como regra, estão desconectados da principal implicação para a evolução do pensamento geológico: a interpretação de que as regiões montanhosas apresentavam uma evolução complexa e não diretamente relacionada à Criação. Durante a segunda metade do século XVII, compreendeu-se que as montanhas se originaram a partir de bacias oceânicas antigas que 
quebraram e arquearam. Apesar de haver dificuldades com relação ao mecanismo de formação das montanhas, a ideia central, de que estratos em sua posição horizontal original, quando pressionados, experimentam encurtamento e, em consequência, espessamento vertical, já está presente no texto de Thomas Burnet. As camadas quebradas (falhadas) e dobradas eram utilizadas, juntamente com os vestígios de organismos marinhos, como evidência do processo de formação (e.g. Burnet 1691, Hooke 1705). Indo além, alguns naturalistas afirmavam que as montanhas eram continuamente erodidas e rebaixadas pela erosão fluvial, sendo seus sedimentos transportados para o mar, onde se depositavam em estratos superpostos.

Dentre o universo dos fósseis, a identificação objetiva de que muitos representavam vestígios de organismos antigos, e a percepção, ainda incipiente, de que o tempo bíblico estava em desajuste com as evidências advindas do registro geológico, são conquistas dos naturalistas do século XVII. Além disso, houve o efetivo reconhecimento, notável como novidade histórica no pensamento ocidental, de que existiram, no passado, organismos diferentes dos seres viventes.

Não havia condições para o aparecimento de uma Geologia em seu sentido moderno, pois a ausência do tempo geológico não permitia o desenvolvimento de conceitos evolutivos, dos organismos e mesmo da paisagem. Ainda assim, muitas ideias, muitos encadeamento de raciocínios, se encontravam em pleno funcionamento. Embora desarticulados, alguns se tornaram o embrião de muitos princípios da Geologia do século XIX, inclusive do uniformitarismo. Em suas radicais implicações, as conquistas dos naturalistas do século XVII podem ser comparadas às relacionadas aos fundamentos da Física ou da Química.

\section{QUESTÕES REFERENTES À CONSTRUÇÃO} DA HISTÓRIA DA GEOLOGIA Muitas vezes, nas abordagens históricas da Geologia, ou mesmo de outros campos das ciências naturais, os homens que propiciaram as condições teóricas de surgimento de princípios científicos se encontram relegados a um segundo ou terceiro planos. Por vezes preteridos por outros que apresentaram ideias próximas, mas que minimizaram, no texto, as questões religiosas. Isto é um efeito da visão em retrospectiva, surge quando olhamos para o passado procurando apenas elementos que se ajustem aos paradigmas do mundo atual, por vezes selecionando apenas pequenos segmentos ou mesmo frases soltas. John Ray, com o seu insipiente ciclo sedimentar, é um notável exemplo desse esquecimento.

No outro extremo, a necessidade de buscar na história, a origem, o descobridor, o primeiro que intuiu, e coletar informações a partir de recortes insuficientes, estabelece, quase sempre, a figura do precursor (Foucault 1997). No caso, aquele que via vestígios de antigos seres vivos onde a maioria das pessoas, na melhor das hipóteses, via pedras semelhantes a conchas ou ossos (e.g. Leonardo da Vinci). Por vezes se detalha a luta "heroica" para fazer valer uma interpretação não compatível com as hipóteses ou crenças existentes. Pelo fato de Steno ter-se referido somente a princípios físicos, com poucas referências ao Dilúvio, fica a impressão de ele ser um geólogo moderno, e inclusive, contrário ao Dilúvio bíblico. Talvez por isso, ele apareça, em resenhas históricas apressadas, como o solitário fundador da Geologia moderna (e.g. Schoch 1982). Nestes históricos, inserido em uma Europa cristã dogmática, Steno está "fora de época”, completamente deslocado do contexto principal. Ao contrário do que transparece sobre ele em alguns textos de história da Geologia, acreditava que suas conclusões eram totalmente consistentes com o Dilúvio Universal (Lamont 2001, Hansen 2009), mas manifestava grande ansiedade em não poder conciliar suas ideias com as Escrituras Sagradas (Halsall 1998). Por opção, a partir de 1675, abandonou a ciência e dedicou-se totalmente à religião.

Colecionar recortes sobre quem disse antes fatos que somente séculos depois seriam aceitos como científicos, levaria a creditar a Thomas Burnet a intuição de uma "teoria geossinclinal". Robert Plot aparece com frequência na parte histórica de livros sobre dinossauros, mas em verdade pensava apenas ter encontrado fragmento de osso de elefante ou a bolsa escrotal de gigante desaparecido.

A visão clássica da história a partir do ponto de vista do que viu antes, do que disse antes, e não foi aceito pelos demais (e.g. Galileu, Steno e Burnet), leva invariavelmente ao entendimento de que os "demais" eram intolerantes, ignorantes, insensíveis à novidade. Porém, em quase todas as situações, passava-se o contrário, a novidade apresentada ainda não estava completa, faltavam elementos importantes e não havia articulação com o saber estabelecido. Os opositores, muitas vezes pessoas de notável erudição, percebiam isso, e sem qualquer má intenção, rejeitavam a ideia. É um processo natural. Toda ideia que, num primeiro momento, contrarie o aceito por quase todos como "realidade", tende a ser rejeitada. Somente após, com o sucesso na resolução dos quebra-cabeças propostos, passa a ser aceita (Kuhn 1976, Lavina 2010).

A partir do século XIX, toda a questão religiosa foi eliminada dos textos técnicos. Este procedimento, absolutamente necessário para a emergência da Geologia como ciência formal, ocasionou a obliteração dos problemas reais que direcionaram a evolução do conhecimento geológico nos seus primórdios. Por 
vezes, recortes do pensamento do século XVII são usados para demonstrar a irracionalidade das argumentações (e.g. Lyell 1830, Stokes 1960, Prothero 2004). Ao contrário do que ocorreu na Física e na Química, o racionalismo absoluto que passou a dominar o pensamento geológico desprezou as conquistas intelectuais do século XVII. Sempre que isto ocorre, fica comprometida a noção de que a ciência é um processo histórico (Lavina 2006).

CONSIDERAÇÕES FINAIS Os homens cultos do século XVII, os homens que deixaram registro escrito de sua forma de pensar o mundo, revelaram por inteiro sua dualidade. Por um lado, selecionaram um recorte do mundo natural (fósseis, montanhas, movimento, gravidade) e passaram a analisá-lo. Na maior parte das vezes, o peso da tradição não permitiu aflorar conflito ou desconforto com a religião. Por vezes, o resultado alcançado, o detalhamento de um processo físico levava, em essência, ao questionamento das Escrituras. Cada sábio estabeleceu um limite interior de até onde poderia chegar o seu questionamento. Quase todos concluíram que sua pesquisa não afrontava o Criador, Sua sabedoria e Seu poder. Restringiram o conflito apenas à Igreja dos homens, à inflexibilidade dos dogmas. Cada um retirava o Criador da relação causa-efeito em estudo, mas o mantinha como a Primeira Causa Eficiente do mundo, o início de tudo (do movimento, da Terra, do homem, do Dilúvio; o criador dos átomos). Como um relógio de alta precisão, o Universo passou a ser descrito como um mecanismo composto por corpos em movimento no tempo e no espaço.

Do outro lado, os teólogos percebiam a avalanche de novas informações sobre os processos naturais empurrando Deus para uma região periférica muito distante do dia a dia das pessoas. Deus estava sendo expulso do paraíso que Ele próprio construíra. Enfraquecida pela Reforma, pelas guerras, pelo fortalecimento do poder real, e pelo aparecimento de classes ricas como banqueiros e comerciantes, que sabiam se defender, a Igreja não teve forças para frear essa nova visão de mundo. No Reino Unido, as novas ideias podiam ser expressas e publicadas sem qualquer restrição, pois o poder maior era o rei e não o papa.

Um dos focos mais críticos da atenção dos sábios foi o Dilúvio Universal. As implicações da construção desenvolvida conflitavam, em termos absolutos, com a interpretação das Escrituras. Em menos de cinquenta anos, o Dilúvio foi analisado como evento científico, detalhado e subdividido em episódios que podiam ser estudados em separado. A origem e, principalmente, a evolução da paisagem, desde a formação de oceanos e continentes, com suas montanhas e vales, levava a conclusões antes impensáveis. A Terra, originalmente plana, lisa como uma cebola, foi, ao final do Dilúvio, destruída por uma catástrofe. Como resultado, os continentes foram formados e as montanhas soerguidas. Toda a vida foi sacrificada, mas deixou registro. Os fósseis podiam ser estudados e auxiliar na compreensão do Dilúvio.

A questão colocada pelos fósseis, em pleno período da transição da episteme da similitude, trazia, internamente, uma contradição facilmente perceptível. Assinalava seres que viveram antes do Dilúvio, o que não era propriamente o centro do problema, mas demonstrava, de modo objetivo, que espécies inteiras não foram salvas por Noé. Havia um conflito evidente no registro fossilífero das rochas, com relação às Escrituras.

Hoje, quando olhamos de relance para o século XVII, não compreendemos como os teólogos e muitos homens cultos não percebiam as semelhanças evidentes entre fósseis e seres. Aparecem como incultos, e o que passava era exatamente o oposto, muitos eram sábios com vasta cultura. Em verdade, estamos desconsiderando a forma como a sociedade criacionista representava o mundo, o modo como organizava o saber, para o qual a semelhança dos fósseis com organismos atuais não tinha significado. De algum modo, os fósseis traíram a epísteme da similitude, pois ao invés de apontar ligações entre o terrestre e o celeste, entre o humano e o divino, questionaram diretamente o evento mais importante depois da Criação.

Se, hoje, esta reconstrução do Dilúvio Universal nos parece despropositada, talvez reflita apenas nosso desconhecimento da História. Se considerarmos a escala do tempo geológico à época, pouco menos de seis mil anos desde a origem da Terra, a evolução acima indicada é totalmente plausível. Neste intervalo de tempo, não existe espaço para uma filosofia uniformitarista. Somos separados do século XVII, não só por trezentos anos, mas fundamentalmente por um abismo (científico, tecnológico e cultural).

Nossa visão de mundo é muito diferente da criacionista. E o ponto de inflexão na mudança está no século XVII, nas novas formas de teorizar, falar, escrever e ler. Lá, naquele tempo, homens como Thomas Burnet, John Woodward, John Ray, Nicolas Steno, Robert Hooke, para citar apenas alguns cuja obra foi voltada a tornar científico o Dilúvio bíblico, foram tão importantes quanto Galileu, Boyle, Leipnitz, Bacon ou mesmo Newton e Descartes.

Agradecimentos Aos colegas José Oliveira, Attico Chassot, Tânia Dutra, Henrique Parisi Kern, Joice Cagliari e aos revisores da RBG, em especial ao professor Celso Dal Ré Carneiro, pelas críticas e sugestões apresentadas. 


\section{Referências}

Bacon F. 1620. Novum Organum/Nova Atlântida. São Paulo, Abril Cultural, 255 p. (Coleção: Os Pensadores, tradução de 1973).

Bark W.C. 1979. Origens da Idade Média. Rio de Janeiro, Zahar Editores, 155 p.

Biblical Chronology s/data. Chronology from Creation of man to the Flood. Disponível em: http://www.nwcreation.net/ biblechrono.html. Acessado em: 20/04/2011.

Blainey G. 2009. Uma breve história do mundo. São Paulo, Fundamento, 342 p.

Burnet T. 1681. Original letter from Thomas Burnet to Isaac Newton. Disponível em http://www.newtonproject. sussex.ac.uk/view/texts/normalized/THEM00252. Acessado em: 23/04/2011.

Burnet T. 1691. The theory of the Earth. London, T. Kinnersley, 716 p. (Reedição de 1816, com extensos comentários).

Burtt E. 1983. As bases metafísicas da ciência moderna. Brasília, UnB, 267 p.

Casini P. 1995. Newton e a consciência européia. São Paulo, UNESP, 253 p.

Cassirer E. 1925. Linguagem, mito e religião. Porto, RésEditora, 120 p.

Cassirer E. 1992. A filosofia do Iluminismo. Campinas, UNICAMP, $472 \mathrm{p}$.

Cassirer E. 1977. Antropologia filosófica. Ensaio sobre o homem. São Paulo, Mestre Jou, 374 p.

Chassot A. 2009. A ciência através dos tempos. São Paulo, Moderna, $280 \mathrm{p}$.

Coelho L. 1988. A ciência na idade média. Lisboa, Guimarães, $157 \mathrm{p}$.

Cresson A. 1963. A filosofia francesa. São Paulo, Difusão Européia do Livro, 131 p.

Cullen K. 2006. Earth Science: The People Behind the Science. New York, Chelsea House, 166 p.

Dalrymple G.B. 1991. The age of the Earth. California, Stanford University Press, 463 p.

Descartes R. 1637 Discurso sobre o método. São Paulo, Hemus, 136 p. (Tradução de 1978).

Descartes R. 1644. Princípios da filosofia. Lisboa, Editorial Presença, 155 p. (Tradução de 1995).

Feynman R. 2001. Física em seis lições. Rio de Janeiro, Ediouro, 205 p.

Fiker R. 1996. O conhecer e o saber em Francis Bacon. São Paulo, Nova Alexandria, 159 p.

Foucault M. 1985. As palavras e as coisas. São Paulo, Martins Fontes, 541 p.

Foucault M. 1997. A arqueologia do saber. Rio de Janeiro, Forense Universitária, 239 p.

Foucault M. 1998. Microfísica do poder. Rio de Janeiro, Graal, 295 p.

Foucault M. 1999a. Vigiar e punir. Petrópolis, Vozes, 262 p.

Foucault M. 1999b. A verdade e as formas jurídicas. Rio de Janeiro, Nau, 158 p.

Galileu Galilei. 1623. O ensaiador. São Paulo, Nova Cultural, 256 p. (Coleção: Os Pensadores, tradução de 2000).

Garcia A. (org.) 1997. Estudos de filosofia medieval. A obra de Raimundo Vier. Curitiba, Vozes, 310 p.
Gardner P. 1995. Teorias da História. Lisboa, Fundação Calouste Gulbenkian, 678 p.

Gayrard-Valy Y. 1994. The story of fossils. In search of vanished worlds. London, Thames and Hudson, 191pp.

Gould S.J. 1982. Seta do tempo, ciclo do tempo. Mito e metáfora na descoberta do tempo geológico. São Paulo, Companhia das Letras, $221 \mathrm{p}$.

Hacking I. 1995. El surgimiento de la probabilidad. Barcelona, Gedisa, 258 p.

Halsall P. 1998. Charles Lyell: Principles of Geology III \& IV. In: Halsall P. (ed.) Modern History Sourcebook. New York, Fordham University, p. 1-27. Disponível em: http://www.fordham.edu/halsall/mod/modsbook.html.

Halstead L.B. \& Sarjeant W.A.S. 1993. Scrotum humanum Brookes - the earliest name for a dinosaur?. Modern Geology, 18:221-224.

Hansen J.M. 2009. On the origin of natural history: Steno's modern, but forgotten philosophy of science. Bull. Geol. Soc. Denmark, 57:1-24.

Hobbes T. 1651. Leviatã, ou a matéria, forma e poder de um Estado eclesiástico e civil. São Paulo, Ícone, 478 p. (Tradução de 2000).

Holmes A. 1913. The age of the Earth. London, Harper \& Brothers, $195 \mathrm{p}$.

Hooke R. 1705. The Posthumous Works of Dr Robert Hooke. Oxford, Gale ECCO Print Editions, 576 p.

Hubble E.P. 1929. A relation between distance and radial velocity among extra-galactic nebulae. Proc. Nat. Acad. Sci. USA, 15:168-173.

Koselleck R. 2006. Futuro passado. Contribuição à semântica dos tempos históricos. Rio de Janeiro, Contraponto, $366 \mathrm{p}$.

Koyré A. 1961. Do mundo fechado ao Universo infinito. Lisboa, Gradiva, 269 p.

Koyré A. 1982. Estudos de história do pensamento científico. Brasília, UnB, 388 p.

Koyré A. 1986. Estudos galilaicos. Lisboa, Publicações Dom Quixote, $426 \mathrm{p}$.

Koyré A. 1992. Considerações sobre Descartes. Lisboa, Editorial Presença, 67 p.

Kuhn T.S. 1976. A estrutura das revoluções científicas. São Paulo, Perspectiva, 257 p.

Kuhn T.S. 1989. A tensão essencial. Lisboa, Edições 70, 422 p.

Lamont A. 2001. Great creation scientists: Nicolas Steno. Creation, 23(4):47-49.

Lavina E.L. 2004. O século XX e as rupturas entre o real científico e o senso comum. Filosofia Unisinos, 5(8):123-37. Disponível em: http://www.unisinos.br/ publicacoes_cientificas/images/stories/Publicacoes/ filosofia_v5n8/art07_lavina.pdf.

Lavina E.L. 2006. A geologia e o processo histórico (ou, sobre como se constrói um passado a marteladas). Gaea Unisinos, 2(1):29-39. Disponível em: http:// www.unisinos.br/publicacoes_cientificas/gaea/art05_ lavina.pdf.

Lavina E.L. 2010. Alfred Wegener e a revolução copernicana da Geologia. Revista Brasileira de Geociências, 40(2):286-299. 
Leibnitz G.W. 1749. Protogaea. São Paulo, Ed. Plêiade, 291 p. (Tradução de 1997 por Papavero N., Teixeira D.M., Ramos M.C.).

Lyell C. 1830. Principles of Geology. London, Penguin Books, 472 p. (Reedição de 1997).

Menegat R. 2008. A invenção da terra moderna por René Descartes: a difícil revolução científica das esferas terrestres. Bol. Geoci. Petrobras, 16(2):421-453.

Moore R. 1956. The Earth we live on. New York, Alfred A. Knopf, 310 p.

Newton I. 1680. Copy letter from Isaac Newton to Thomas Burnet. Disponível em: http://www.newtonproject. sussex.ac.uk/view/texts/normalized/THEM00253. Acessado em: 23/04/2011.

Newton I. 1704. Óptica. In: Galileu, Newton. São Paulo, Nova Cultural, p. 171-205. (Coleção: Os Pensadores).

Palmer D. 2005. Earth time: exploring the deep past from Victorian England to the Grand Canyon. Chichester, Wiley, 436 p.

Patterson C. 1956. Age of Meteorites and the Earth. Geochim. Cosmochim. Ac., 10:230-237.

Pernold R. 1997. Luz sobre a idade media. Sintra, Publicações Europa-América, 208 p.

Plot R. 1677. The natural history of Oxford-Shire. London, John Burman, 349 p.

Prothero D.R. 2004. Bringing fossils to life. An introduction to Paleobiology. Boston, McGraw Hill, 505 p.

Ray J. 1692. Miscellaneous discourses concerning the dissolution and changes of the world. Hildesheim, Georg Olms, 260 p. (Reedição de 1968).

Ray J. 1713. Three physico-theological discourses. London, William Innys, $456 \mathrm{p}$.

Rudwick M.S.J. 1976. The meaning of fossils. Chicago, The University of Chicago Press, 287 p.

Russell B. 1982. História da filosofia ocidental. Brasília, Companhia Editora Nacional, 391 p.

Rutherford W. 1991. Pitágoras. São Paulo, Mercuryo, 130 p.
Sá A.M. 1944. Os precursores de Descartes. Lisboa, Couto Martins, $156 \mathrm{p}$.

Schoch R.M. 1989. Stratigraphy, principles and methods. New York, Van Nostrand Renhold, 375 p.

Scilla A. 1670. La vana speculazione disingannata dal senso. Firenze, Giunti Editore, 142 p. (Reeditado em 1996).

Steno N. 1667. Canis carchariae dissectum caput. In: Steno N. Elementorum myologiae specimen, seu musculi descriptio geometrica. Cui accedunt canis carchariae dissectum caput, et dissectus piscis ex canum genere. Florença, Typographia sub signo Stellae, p. 69-124.

Steno N. 1669. The Prodomus of Nicolaus Steno's. Dissertation concerning a solid naturally contained within a solid. New York, The MacMillan Company, 283 p. (Tradução de 1916).

Stokes W.L. 1960. Essentials of Earth history. New Jersey, Prentice-Hall Inc., 468 p.

Torquemada A. 1573. Jardín de flores curiosas (tomo 1). El Parnasillo, Simancas Ediciones S.A., 187 p. (Reimpressão em 2005).

Trevor-Roper H. 2001. The crisis of the seventeenth century: religion, the Reformation and social change. Indianapolis, Liberty Fund, 465 p.

Zir A. 2005. A história da nossa (concepção de) natureza. Colecção Naturarte, 1:14-15.

Whiston W. 1696. A New Theory of the Earth. London, Benjamin Tooke, $497 \mathrm{p}$.

Woodward J. 1695. An essay toward a natural history of the Earth and terrestrial bodies, especially minerals. London, A. Betterworth and W. Taylor, 304 p.

Wyllie P.J. 1979. A Terra. Nova Geologia global. Lisboa, Fundação Calouste Gulbenkian, 384 p.

Manuscrito ID 19362

Submetido em 13 de outubro de 2010 Aceito em 07 de fevereiro de 2012 